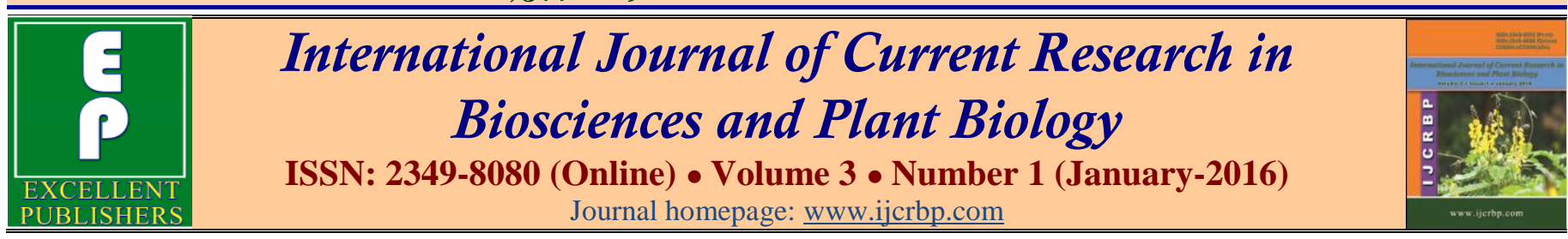

\title{
Floristic Inventory of Woody Species of the Oku Sacred Forest in the North-West Cameroon, Theoretical and Philosophical Approach
}

\author{
Emmanuel Noumi ${ }^{1}$ and Guy Alain Tagne Tiam²* \\ ${ }^{1}$ Laboratory of Plant Biology, Higher Teacher Training College, University of Yaounde I, BP: 47 Yaoundé, Cameroon \\ ${ }^{2}$ Faculty of Science, University of Yaounde I, BP: 16591 Yaoundé, Cameroon \\ *Corresponding author.
}

\section{A b stract}

This survey articulates around three aims; (1) to study the vegetation structure and woody species diversity in the hilly Oku sacred forest $(2200-2300 \mathrm{~m}$ of altitude) of northwestern Cameroon, (2) to compare our results with those of other tropical sacred forests, and (3) to appreciate the hygrothermality of the plant species. A quantitative inventory was realized on trees with diameter at breast height $\geq 10 \mathrm{~cm}$ covering a cumulative surface area of 1.25 -ha, from 9 rectangular plots of $50 \mathrm{~m} \times 25 \mathrm{~m}\left(1250 \mathrm{~m}^{2}\right)$. Standard methodology to calculate floristic diversity was employed. A total of 934 trees belonging to 31 species, 27 genera and 19 families were recorded with a total basal area of $246.87 \mathrm{~m}^{2}$ per hectar. Most trees had a height between 10 and $15 \mathrm{~m}$ and diameter of $10-20 \mathrm{~cm}$. However some individuals reached heights of 25 to $30 \mathrm{~m}$. Three species namely Schefflera abyssinica (1 individual), Schefflera mannii (2 individuals) and Syzygium guineense (2 individuals) had a diameter of $220-230 \mathrm{~cm}$. The 4 most important families in term of density, diversity and dominance were Araliaceae, Myrtaceae, Meliaceae and Rubiaceae. They represented 150.7 of Family Importance Value (FIV). The species composition was dominated by five common species (16.12\%) (Schefflera mannii, Carapa grandiflora, Syzygium guineense, Xymalos monospora and Piptadeniastrum africanum), representing 162.47 of the Index of Value importance (IVI). Three plant species were represented by only one individual. The peculiarity of the Oku sacred forest is the presence and high IVI (26.55) of Piptadeniastrum africana, the lone Leguminosae, a characteristic of mesophile forests (order of the PiptadenioCeltidetalia). The Oku sacred forest has low species diversity, considerably high stem abundance compared to most forests of tropical regions and a highest dominance. The forest structure and formation is characterised by big trees (in terms of diameter), covered from top to bottom by the strangler epiphytes. With respect to species climatological considerations, the Oku sacred forest is dominated by hygro-oligothermal (afro-montane) vegetation, hygro-mesothermal (submontane) vegetation and hygromegathermal (lower and middle altitudes) vegetation. All these characteristics argue for the syngenetic status of Oku sacred forest.
\end{abstract}

\section{Introduction}

The Cameroon Mountains form a floristic archipelago similar to that of eastern and southern Africa (White,

\section{Article Info}

Accepted: 23 December 2015

Available Online: 06 January 2016

\section{Keywords}

Biodiversity

Oku massif

Sacred forest

Woody flora
1983) and is host to important floristic sites. One of such important sites is the Oku mountain situated at the northwestern edge of Cameroon, from latitude $6^{\circ} 07^{\prime}$ $6^{\circ} 17^{\prime}$ and longitude $10^{\circ} 20^{\prime}-10^{\circ} 35^{\prime}$ UTM $32 \mathrm{~N}$ - WGS 
84. It summits at $3011 \mathrm{~m}$ (also known as Kilum summit) is only second to mount Cameroon $(4095 \mathrm{~m})$. On the western slope is the Ijim Crete that reaches $2500 \mathrm{~m}$ in altitude. This survey was carried out in the northwestern sector of the sacred forest with altitude between 2200 2300m (Fig. 1).

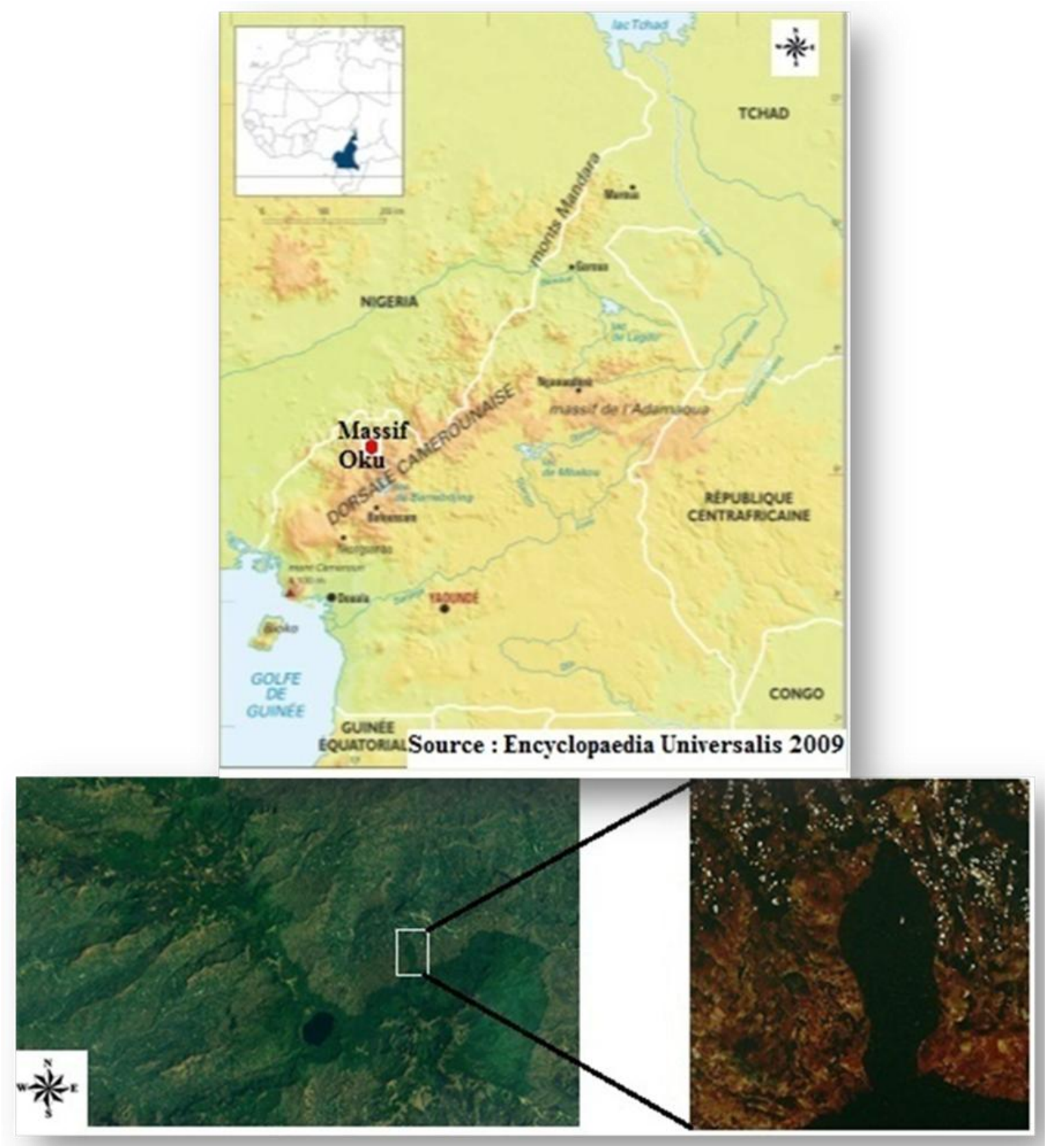

Fig. 1: Location of the Oku sacred forest along the Cameroon Mountain (top). View of the sacred forest from google map(https://www.google.com/maps/). The white rectangle indicates the position of the sacred forest (bottom left) and Oku Lake (bottom right). The white point on the dark strip is reflection of light by the metal sheet of the roofing of the slots of the rituals. The small white points in hood on the dark strip represent the houses of dwelling of the local populations.

The Oku sacred forest is located in a large valley on the Oku Mountain. It is remarkable for its dense vegetation delimited by a row of Prunus africana. Two ritual houses have been raised in the middle of the sacred forest. The survival and management of the sacred forest and its biological diversity rest on the customary laws such as 
restriction to debark important species such as Prunus africana for medicinal purposes, felling of soft wood like Polyscias fulva for sculptures and other art works, burning from traditional agriculture or hunting for bushmeat.

This study is based one an axiom: a plant formation is a group of species gathered by the non reciprocal attraction exercised on them by the various factors of the middle. The theory is: to discern a plant formation like a group of species gathered by the non reciprocal attraction exercised on them by the various factors of the middle, and to establish some flora - middle affinities. The philosophy developed from this was to focus attention on the flora and the vegetation and to have the visions of the phenomena who took place before the present stage.

Several studies on the structure and biodiversity have been realised in the low and middle altitudes forests of African, Malagasy and the Neotropic regions (Villanueva, 1991; Pichiger et al., 1992, 1996; Lejoly, 1995; Rabevohitra et al., 1996; Sonke, 1998; Collin, 1998; Rakotomalaza and Messmer, 1999; D'Amico and Gautier, 2000; Senterre et al., 2004). These studies highlighted quantitative measures for families and the species diversities of these forest types. Some investigations in the submontane and afro-montane forests have been conducted following similar methodology (Mohandass and Davidar, 2009; Noumi, 2012, 2013 and 2015). Could the structural characteristics and the species diversity of the Oku sacred forest permit a singular scientific status just as its current social status?

The goals of the present survey were (1) to inventories tree species in the Oku sacred forest by means of forest plots, while taking into account the trees species $\geq 10 \mathrm{~cm}$ diameter at breast height (dbh), (2) to quantify the parameters of diversity and structure, and (3) to characterize the plant formation in relation to existing data in various forests.

\section{Study area}

Oku area has humiferous ferralitic soils (Hawkins et al., 1965) classified by FAO as ferralitic sols. McLeod (1987) identified the presence of three types of ferralitic soils in the $\mathrm{Oku}$ forest area: trachyte, basalt and cemented ashes. These soils have rich organic content because of its altitude and climate. The massif carries a highlander forest interrupted by herbaceous vegetation carpet where goats (Capra hircus, Caprinae) and sheeps
(Ovis ammon, Ovinae) (Fig. 2) graze. These herbaceous zones make as agricultural earth office (Momo, 2009).

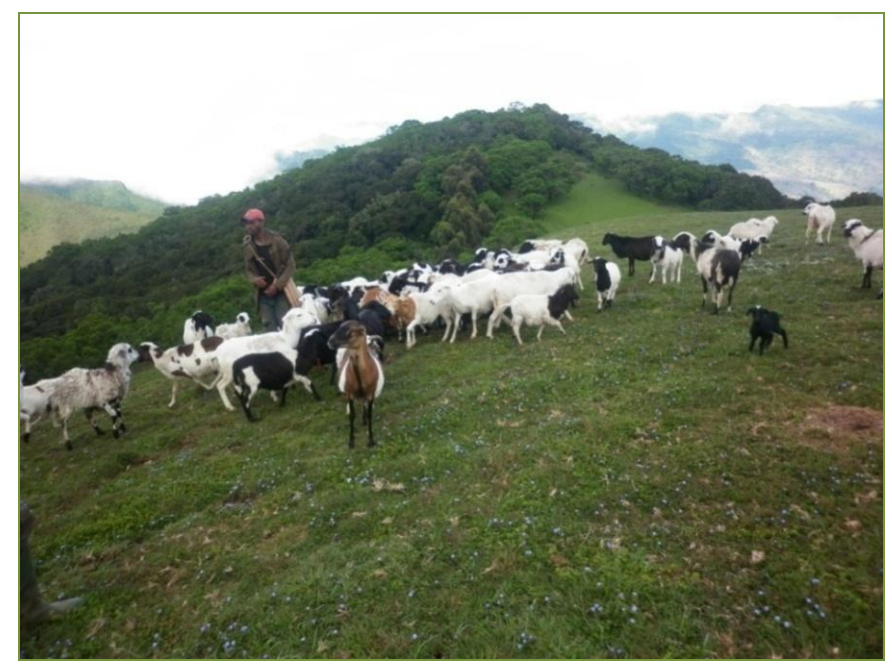

Fig. 2: A shepherd and his sheeps on the summit of the Oku massif.

The local climate of the Oku forest area can be deduced from that of Kumbo city (1000m altitude) situated at $30 \mathrm{~km}$ from the Kilum summit, with annual precipitations of $2305.1 \mathrm{~mm}$, average annual temperature of $19.8^{\circ} \mathrm{C}$ and relative humidity above $86 \%$ throughout the year. The ombrothermic diagram is presented in Fig. 3. We thus expected the rainfall in the Oku forest to be higher because of higher altitude than Kumbo.

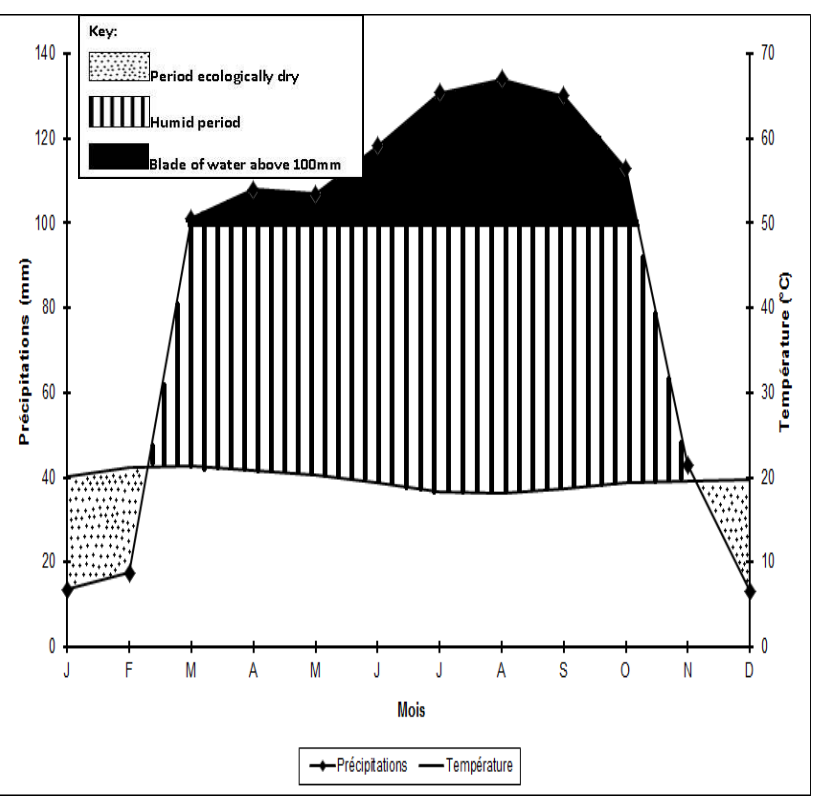

Fig. 3: Ombrothermic diagram of Kumbo by Bagnouls and Gaussen (1957), modified according to the method of Walter and Lieth (1964): on the curve of monthly mean of rainfalls, the scale is reduced to the $1 / 10$ from $100 \mathrm{~mm}$. (Source: Divisional delegation of Agriculture at Kumbo). 
The local climate of the Oku forest area can be deduced from that of Kumbo city (1000m altitude) situated at 30 $\mathrm{km}$ from the Kilum summit, with annual precipitations of $2305.1 \mathrm{~mm}$, average annual temperature of $19.8^{\circ} \mathrm{C}$ and relative humidity above $86 \%$ throughout the year. The ombrothermic diagram is presented in Fig. 3. We thus expected the rainfall in the Oku forest to be higher because of higher altitude than Kumbo.

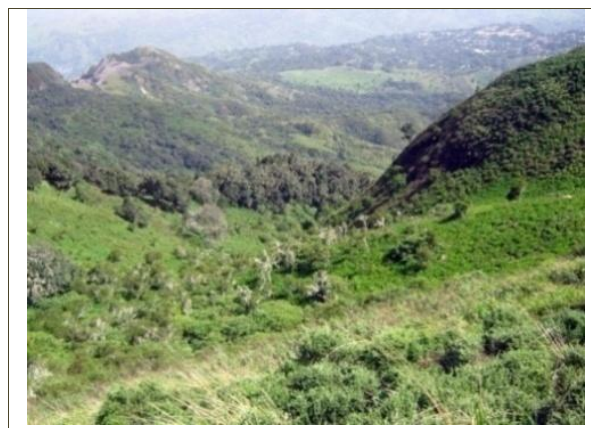

Landscape and vegetation of some summits

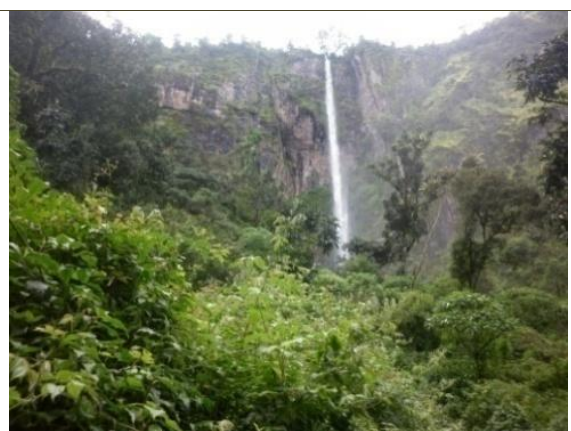

Fall (blank) of a tributary, to the level of a subsidence, in a talweg

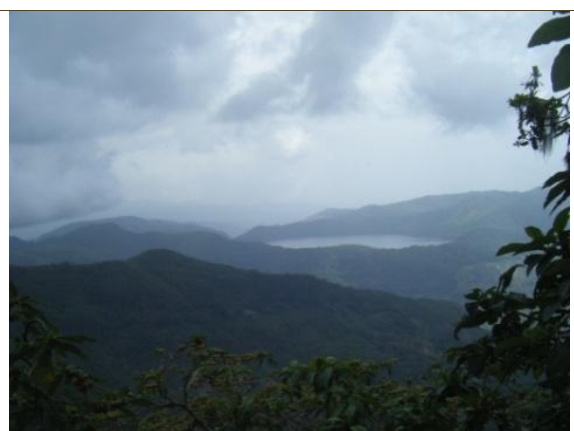

Oku lake in a crater (plane rear), $2200 \mathrm{~m}$ of altitude

Fig. 4: Cross section of some landscapes of the Oku massif.

The high rainfall around this forest area has created a dense network of permanent water tributaries and waterfalls (Cheek et al., 2000). Part of the water flows into River Katsena and Benue via the Lui village or toward the Mbam down to River Sanaga. The smaller tributaires nourish Lake Oku at altitude 2200-2300m (Fig. 4). The natives are constituted by the populations of 3 villages or "'fondon"' that share the sommits: Oku and Nso villages (in the Bui Division) and Kilum village (in Boyo Division). The emigrants are especially the Bamilékés, planters of coffee (Coffea arabica, Rubiaceae) and the Bororos or Fulanis, nomads and breeder of the bovidae and installed in the prairies enclosed inside the forests. They live there since 60 years (Thomas et al., 2001).

\section{Materials and methods}

Fieldwork was conducted in 2012-2013 in the Oku sacred forest. Woody plant diversity was inventoried by sampling nine plots of $25 \mathrm{~m} \times 50 \mathrm{~m}\left(1250 \mathrm{~m}^{2}\right)$. These plots were all identical to the mesologic and physionomic point of view. A trail of $50 \mathrm{~m}$ in the center of rectangle facilitated the sampling of $12.5 \mathrm{~m}$ on one side, then on the other of the trail. All trees and lianas with diameter at breast height $(\mathrm{dbh}) \geq 10 \mathrm{~cm}$, i.e., $130 \mathrm{~cm}$ above the ground were measured. Some species are determined on foot (Norman, 1965, Vivien and Faure, 1985). Unidentified species were collected as vouchers for further identification at the laboratory of Botany of the Department of the Biological Sciences, Higher Teachers' Training College. Confirmation of the identification were also done at the National Herbarium of Cameroon (YA) with the assistance of mounted specimens, identification keys, local flora, and check list (Aubréville et al., 19631998), Flora of West Tropical Africa, FWTA (Hutchinson and Dalziel, 1954-1972), and some books (Norman, 1965; Cheek et al., 2000; Cable and Cheek, 1998).

\section{Floristic analysis}

The floristic data was used to build a speciesaccumulation curve as attempt to evaluate the strength of the sampling (Gounot, 1969). Different indices were also calculated; basal area defined as the projected surface area covered all stems measured at $\geq 10 \mathrm{~cm}$ dbh. We used data on species and family abundance to calculate the Importance Value Index (IVI; Curtis and Mc-Intosh, 1951; Cottam and Curtis, 1956) and the Family Importance Value index (FIV; Mori et al. 1983). Some details are given in supplementary material (Appendix 3)

We equally used the Shannon and Pielou indices to measure diversity and equitability (Shannon and Weaver, 1949; Pielou, 1966).

$$
H=-\sum_{i=1}^{s} \frac{n_{i}}{N} \log _{2} \frac{n_{i}}{N}
$$

Equitability of EQ = ISH/ $\log _{2} \mathrm{~S}$;

Where, $S$ is the number of species of a given parcel; $\mathrm{n}_{\mathrm{i}}$ is the number of the species $\mathrm{i}$ and $\mathrm{N}$ the strength of all species. 


\section{Phytogeographic and phytosociologic analysis}

Information on species distribution was obtained from the literature and floras (Keay and Hepper, 1954-1972; Aubréville and Leroy, 1961-1992, 1963-1978; Hallé, 1961-1987; Letouzey, 1968, 1985; Lebrun and Stork, 1991-1997) and of other publications (White, 1983; Stuart and Cheek, 1998). The analysis concerned 30 determined taxons to the level of the species. Phytogeographic classification was based on White $(1979,1983)$ as:

\section{A. Widely distributed species}

- Afro-tropical (At); species present in the intertropical African zone;

- $\quad$ At + sub-At

- Pantropical (Pant); species present in Africa, America and tropical Asia;

- Paleotropical (Pal); species known in Africa and tropical Asia as well as to Madagascar and in Australia;

- Species of liaison; species where the distribution covers two or several floristic African regions and that are extensively widespread or abundant in places to be considered like sub-endemic (G-Sz). These elements are either the chorological or ecological transgressors, either merely the species with large distribution and with enough uniform ecology.

\section{B. Guineo - Congolese sub-endemic species}

- Species that spread to the adjacent transition zones or that overflow slightly beyond these last as marginal intrusion species or as species forming some satellites populations weakly distant.

- Guineo- Congolese endemic species.

+ Omni-Guinéo-Congolese (G): present in the whole Guineo-Congolese region;

+ Centro-Guineo-Congolese $(\mathrm{Cg})$ : species whose distribution covers the domain of lower Guinean (from the South of Nigeria to the Democratic Republic of Congo) and Congolese domain;

+ Lower Guinean (Lg): species widespread in the under lower Guinean center, from the South of Nigeria to the South of Republic of Congo;
+ Endemic of the Cameroonian afro-montane archipelago, including Bioko (ex Fernando po) possibly (End-Cam).

The botanical nomenclature used is the one adopted by Lebrun and Stork (1991-1997). The taxonomic authorities of all species listed in this survey are given in supplementary material (Appendix 1).

\section{Phytosociological groups of African forests}

Ombrophile forest groups:

+ The equatorial ombrophile forests. Class of the Strombosio-Parinarietea (Lebrun and Gilbert, 1954) (Str).

+ The basis and average altitudes ombrophile forests. Order of the Gilbertiodendretalia dewevrei (Lebrun and Gilbert, 1954) (Gil)

+ The ombrophile submontane forests. Order of the Garcinietalia (Noumi, 1998) (Gar)

+ The ombrophile afromontane forests. Order of the Ficalhoeto-Podocarpetalia (Lebrun and Gilbert, 1954) (Fic)

Mesophile forest (hemi - deciduous) Groups:

+ The hemi-deciduous forests. Order of the Piptadenio-celtidetalia (Lebrun and Gilbert, 1954) (Pip).

Secondary forest groups:

+ The secondary forests of low and middle altitudes. Class of the Musango-Terminalietea (Lebrun and Gilbert, 1954) (Mus)

+ The mountane recru and secondary forests. Order of the Polyscietalia fulvae (Lebrun and Gilbert, 1954) (Pol).

\section{Results}

\section{Structure of the forest}

The inventory in the Oku sacred forest has been summarised from nine plots of $25 \mathrm{~m} \times 50 \mathrm{~m}$ each, covering a total surface of $11250 \mathrm{~m}^{2}$ (1.125 ha). A total of 934 individuals of $\mathrm{dbh} \geq 10 \mathrm{~cm}$ were identified, consisting 31 species (Table 1), 27 genera and 19 families. The species recorded in the Oku sacred forest are quantitatively represented in Fig. 5-1. 
Table 1. Floristic list of the montane sacred forestof Oku, with the number of individuals by class average of diameter $(\mathrm{dbh} \geq 10 \mathrm{~cm})$.

\begin{tabular}{|c|c|c|c|c|c|c|c|c|c|c|c|c|c|c|c|c|c|c|c|c|c|c|c|c|c|c|c|c|c|}
\hline Species & $\begin{array}{l}10 \\
\text { to } \\
20\end{array}$ & $\begin{array}{l}20 \\
\text { to } \\
30\end{array}$ & $\begin{array}{l}30 \\
\text { to } \\
40\end{array}$ & $\begin{array}{l}40 \\
\text { to } \\
50\end{array}$ & $\begin{array}{l}50 \\
\text { to } \\
60\end{array}$ & $\begin{array}{l}60 \\
\text { to } \\
70\end{array}$ & $\begin{array}{l}70 \\
\text { to } \\
80\end{array}$ & $\begin{array}{l}80 \\
\text { to } \\
90\end{array}$ & $\begin{array}{c}90 \\
\text { to } \\
100\end{array}$ & $\begin{array}{c}100 \\
\text { to } \\
110\end{array}$ & $\begin{array}{c}110 \\
\text { to } \\
120\end{array}$ & $\begin{array}{c}120 \\
\text { to } \\
130\end{array}$ & $\begin{array}{c}130 \\
\text { to } \\
140\end{array}$ & $\begin{array}{c}140 \\
\text { to } \\
150\end{array}$ & $\begin{array}{c}150 \\
\text { to } \\
160\end{array}$ & $\begin{array}{c}160 \\
\text { to } \\
170\end{array}$ & $\begin{array}{c}170 \\
\text { to } \\
180\end{array}$ & $\begin{array}{c}180 \\
\text { to } \\
190\end{array}$ & $\begin{array}{c}190 \\
\text { to } \\
200\end{array}$ & $\begin{array}{c}200 \\
\text { to } \\
210\end{array}$ & $\begin{array}{c}210 \\
\text { to } \\
220\end{array}$ & $\begin{array}{c}220 \\
\text { to } \\
230\end{array}$ & $\begin{array}{c}230 \\
\text { to } \\
240\end{array}$ & $\begin{array}{c}240 \\
\text { to } \\
250\end{array}$ & $\begin{array}{c}250 \\
\text { to } \\
260\end{array}$ & $\begin{array}{c}260 \\
\text { to } \\
270\end{array}$ & $\begin{array}{c}270 \\
\text { to } \\
280\end{array}$ & $\begin{array}{c}280 \\
\text { to } \\
290\end{array}$ & $\begin{array}{l}\text { Total } \\
\text { trees }\end{array}$ \\
\hline Aidia micrantha & 20 & 4 & 1 & 1 & 0 & 0 & 0 & 0 & 0 & 0 & 0 & 0 & 0 & 0 & 0 & 0 & 0 & 0 & 0 & 0 & 0 & 0 & 0 & 0 & 0 & 0 & 0 & 0 & 26 \\
\hline Allophylus bullatus & 15 & 0 & 0 & 0 & 0 & 0 & 0 & 0 & 0 & 0 & 0 & 0 & 0 & 1 & 0 & 1 & 0 & 0 & 0 & 0 & 0 & 0 & 0 & 0 & 0 & 0 & 0 & 0 & 17 \\
\hline Ardisia cynosa & 2 & 1 & 0 & 0 & 0 & 0 & 0 & 0 & 0 & 0 & 0 & 0 & 0 & 0 & 0 & 0 & 0 & 0 & 0 & 0 & 0 & 0 & 0 & 0 & 0 & 0 & 0 & 0 & 3 \\
\hline Bersama abyssinica & 20 & 10 & 7 & 2 & 1 & 0 & 0 & 0 & 0 & 0 & 0 & 0 & 0 & 0 & 0 & 0 & 0 & 0 & 0 & 0 & 0 & 0 & 0 & 0 & 0 & 0 & 0 & 0 & 40 \\
\hline Bersama engleriana & 10 & 5 & 0 & 0 & 0 & 0 & 0 & 0 & 0 & 0 & 0 & 0 & 1 & 1 & 0 & 0 & 0 & 1 & 0 & 0 & 0 & 0 & 0 & 0 & 0 & 0 & 0 & 0 & 18 \\
\hline Carapa grandiflora & 190 & 55 & 19 & 13 & 5 & 2 & 0 & 0 & 0 & 0 & 0 & 0 & 0 & 0 & 0 & 0 & 0 & 0 & 0 & 0 & 0 & 0 & 0 & 0 & 0 & 0 & 0 & 0 & 284 \\
\hline Clausena anisata & 7 & 0 & 0 & 0 & 0 & 0 & 0 & 0 & 0 & 0 & 0 & 0 & 0 & 0 & 0 & 0 & 0 & 0 & 0 & 0 & 0 & 0 & 0 & 0 & 0 & 0 & 0 & 0 & 7 \\
\hline Croton macrostachyus & 8 & 1 & 3 & 0 & 0 & 0 & 0 & 0 & 0 & 0 & 0 & 0 & 0 & 0 & 0 & 0 & 0 & 0 & 0 & 0 & 0 & 0 & 0 & 0 & 0 & 0 & 0 & 0 & 12 \\
\hline Eugenia gilgii & 12 & 6 & 1 & 0 & 0 & 0 & 1 & 0 & 0 & 0 & 0 & 0 & 0 & 0 & 0 & 0 & 0 & 0 & 0 & 0 & 0 & 0 & 0 & 0 & 0 & 0 & 0 & 0 & 20 \\
\hline Ficus macrophylla & 0 & 0 & 0 & 0 & 0 & 0 & 0 & 0 & 0 & 0 & 0 & 0 & 0 & 0 & 0 & 0 & 0 & 0 & 1 & 0 & 0 & 0 & 0 & 0 & 0 & 0 & 0 & 0 & 1 \\
\hline Ficus thonningii & 1 & 0 & 1 & 1 & 0 & 1 & 1 & 0 & 0 & 0 & 0 & 0 & 1 & 0 & 0 & 0 & 1 & 0 & 1 & 0 & 1 & 0 & 0 & 0 & 0 & 0 & 1 & 1 & 11 \\
\hline Ixora breviflora & 8 & 3 & 1 & 1 & 1 & 1 & 0 & 0 & 0 & 0 & 1 & 0 & 0 & 0 & 0 & 0 & 0 & 0 & 0 & 0 & 0 & 0 & 0 & 0 & 0 & 0 & 0 & 0 & 16 \\
\hline Maesa lanceolata & 4 & 0 & 0 & 0 & 0 & 0 & 0 & 0 & 0 & 0 & 0 & 0 & 0 & 0 & 0 & 0 & 0 & 0 & 0 & 0 & 0 & 0 & 0 & 0 & 0 & 0 & 0 & 0 & 4 \\
\hline Maesa sp. & 3 & 0 & 0 & 0 & 0 & 0 & 0 & 0 & 0 & 0 & 0 & 0 & 0 & 0 & 0 & 0 & 0 & 0 & 0 & 0 & 0 & 0 & 0 & 0 & 0 & 0 & 0 & 0 & 3 \\
\hline Neuropeltis acuminata & 20 & 0 & 0 & 0 & 0 & 0 & 0 & 0 & 0 & 0 & 0 & 0 & 0 & 0 & 0 & 0 & 0 & 0 & 0 & 0 & 0 & 0 & 0 & 0 & 0 & 0 & 0 & 0 & 20 \\
\hline Nuxia congesta & 6 & 0 & 2 & 3 & 1 & 2 & 2 & 2 & 1 & 1 & 0 & 2 & 2 & 0 & 0 & 0 & 0 & 2 & 0 & 0 & 0 & 1 & 0 & 0 & 0 & 1 & 0 & 0 & 28 \\
\hline Piptadeniastrum africanum & 12 & 4 & 2 & 1 & 0 & 2 & 3 & 3 & 1 & 2 & 0 & 2 & 3 & 1 & 0 & 2 & 2 & 1 & 1 & 0 & 0 & 0 & 0 & 0 & 0 & 0 & 0 & 0 & 42 \\
\hline Pittosporum viridiflorum & 2 & 2 & 1 & 0 & 0 & 0 & 0 & 0 & 0 & 0 & 0 & 0 & 0 & 0 & 0 & 0 & 0 & 0 & 0 & 0 & 0 & 0 & 0 & 0 & 0 & 0 & 0 & 0 & 5 \\
\hline Polyscias fulva & 1 & 0 & 2 & 0 & 0 & 0 & 0 & 0 & 0 & 0 & 0 & 0 & 0 & 0 & 0 & 0 & 0 & 0 & 0 & 0 & 0 & 0 & 0 & 0 & 0 & 0 & 0 & 0 & 3 \\
\hline Psydrax arnoldiana & 25 & 2 & 0 & 0 & 0 & 0 & 0 & 0 & 0 & 0 & 0 & 0 & 0 & 0 & 0 & 0 & 0 & 0 & 0 & 0 & 0 & 0 & 0 & 0 & 0 & 0 & 0 & 0 & 27 \\
\hline Rapanea melanophloeos & 1 & 1 & 0 & 0 & 0 & 0 & 0 & 0 & 0 & 0 & 0 & 0 & 0 & 0 & 0 & 0 & 0 & 0 & 0 & 0 & 0 & 0 & 0 & 0 & 0 & 0 & 0 & 0 & 2 \\
\hline Rauvolfia macrophylla & 40 & 0 & 0 & 0 & 0 & 0 & 0 & 0 & 0 & 0 & 0 & 0 & 0 & 0 & 0 & 0 & 0 & 0 & 0 & 0 & 0 & 0 & 0 & 0 & 0 & 0 & 0 & 0 & 40 \\
\hline Rytigynia neglecta & 25 & 2 & 0 & 0 & 0 & 0 & 0 & 0 & 0 & 0 & 0 & 0 & 0 & 0 & 0 & 0 & 0 & 0 & 0 & 0 & 0 & 0 & 0 & 0 & 0 & 0 & 0 & 0 & 27 \\
\hline Schefflera abyssinica & 0 & 0 & 0 & 0 & 0 & 0 & 0 & 0 & 0 & 0 & 0 & 0 & 0 & 0 & 0 & 0 & 0 & 0 & 0 & 0 & 0 & 0 & 1 & 0 & 0 & 0 & 0 & 0 & 1 \\
\hline Schefflera mannii & 3 & 0 & 2 & 1 & 2 & 1 & 1 & 2 & 1 & 0 & 2 & 1 & 0 & 1 & 2 & 1 & 1 & 2 & 4 & 4 & 2 & 2 & 3 & 1 & 0 & 1 & 1 & 0 & 41 \\
\hline Shirakiopsis elliptica & 2 & 0 & 0 & 0 & 0 & 0 & 0 & 0 & 0 & 0 & 0 & 0 & 0 & 0 & 0 & 0 & 0 & 0 & 0 & 0 & 0 & 0 & 0 & 0 & 0 & 0 & 0 & 0 & 2 \\
\hline Solanecio mannii & 11 & 1 & 0 & 0 & 0 & 0 & 0 & 0 & 0 & 0 & 0 & 0 & 0 & 0 & 0 & 0 & 0 & 0 & 0 & 0 & 0 & 0 & 0 & 0 & 0 & 0 & 0 & 0 & 12 \\
\hline Syzygium guineense & 30 & 7 & 6 & 1 & 2 & 1 & 5 & 4 & 4 & 2 & 3 & 2 & 2 & 2 & 2 & 2 & 0 & 1 & 0 & 1 & 0 & 0 & 1 & 0 & 0 & 1 & 1 & 1 & 81 \\
\hline Trema orientalis & 3 & 1 & 0 & 0 & 0 & 0 & 0 & 0 & 0 & 0 & 0 & 0 & 0 & 0 & 0 & 0 & 0 & 0 & 0 & 0 & 0 & 0 & 0 & 0 & 0 & 0 & 0 & 0 & 4 \\
\hline Xymalos monospora & 98 & 24 & 8 & 5 & 1 & 0 & 0 & 0 & 0 & 0 & 0 & 0 & 0 & 0 & 0 & 0 & 0 & 0 & 0 & 0 & 0 & 0 & 0 & 0 & 0 & 0 & 0 & 0 & 136 \\
\hline Zanthoxylum heitzii & 0 & 0 & 0 & 0 & 0 & 0 & 0 & 0 & 0 & 0 & 0 & 0 & 0 & 0 & 0 & 0 & 0 & 0 & 0 & 1 & 0 & 0 & 0 & 0 & 0 & 0 & 0 & 0 & 1 \\
\hline Total & 579 & 129 & 56 & 29 & 13 & 10 & 13 & 11 & 7 & 5 & 6 & 7 & 9 & 6 & 4 & 6 & 4 & 7 & 7 & 6 & 3 & 3 & 5 & 1 & $\mathbf{0}$ & 3 & 3 & 2 & 934 \\
\hline
\end{tabular}




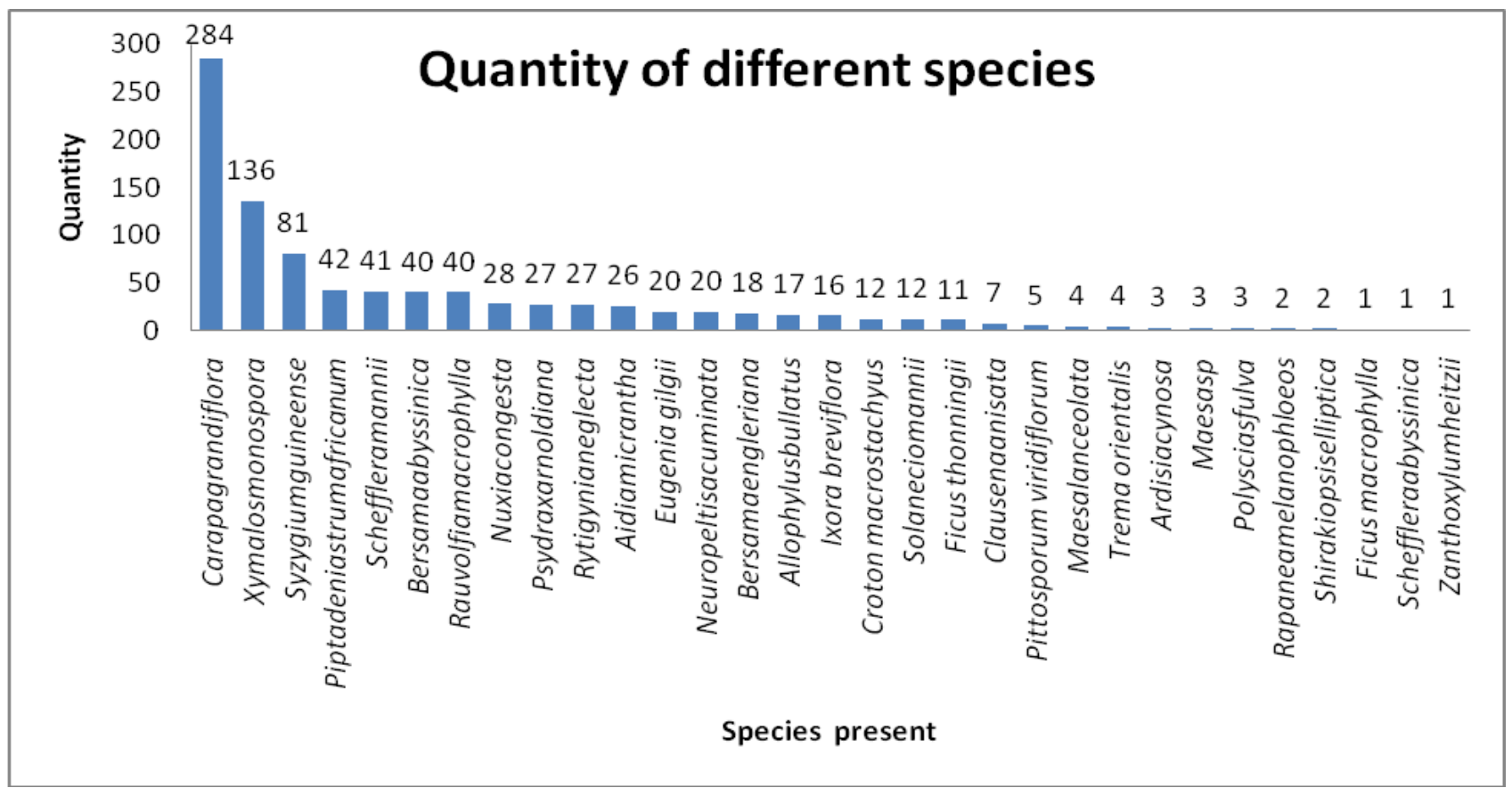

Fig. 5-1: Quantitative distribution of floristic diversity. The numbers of recorded individuals are indicated for every species.

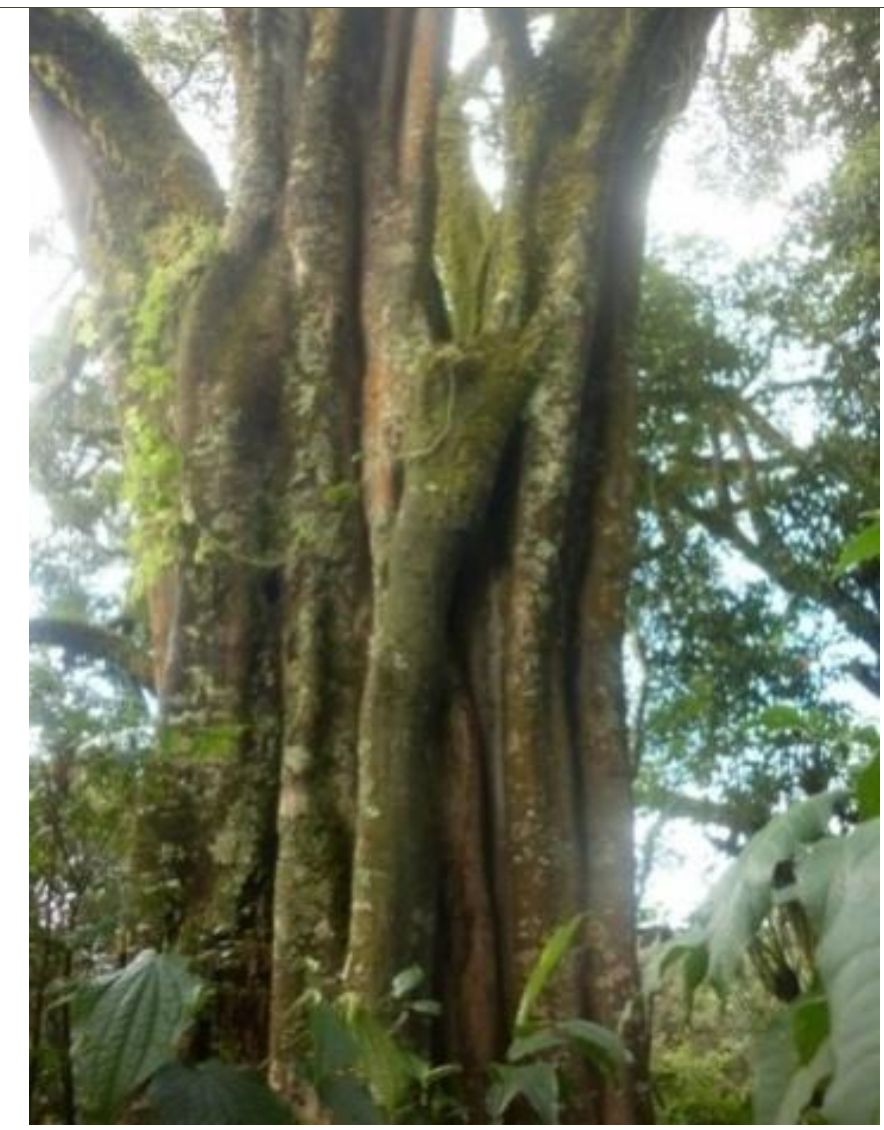

A
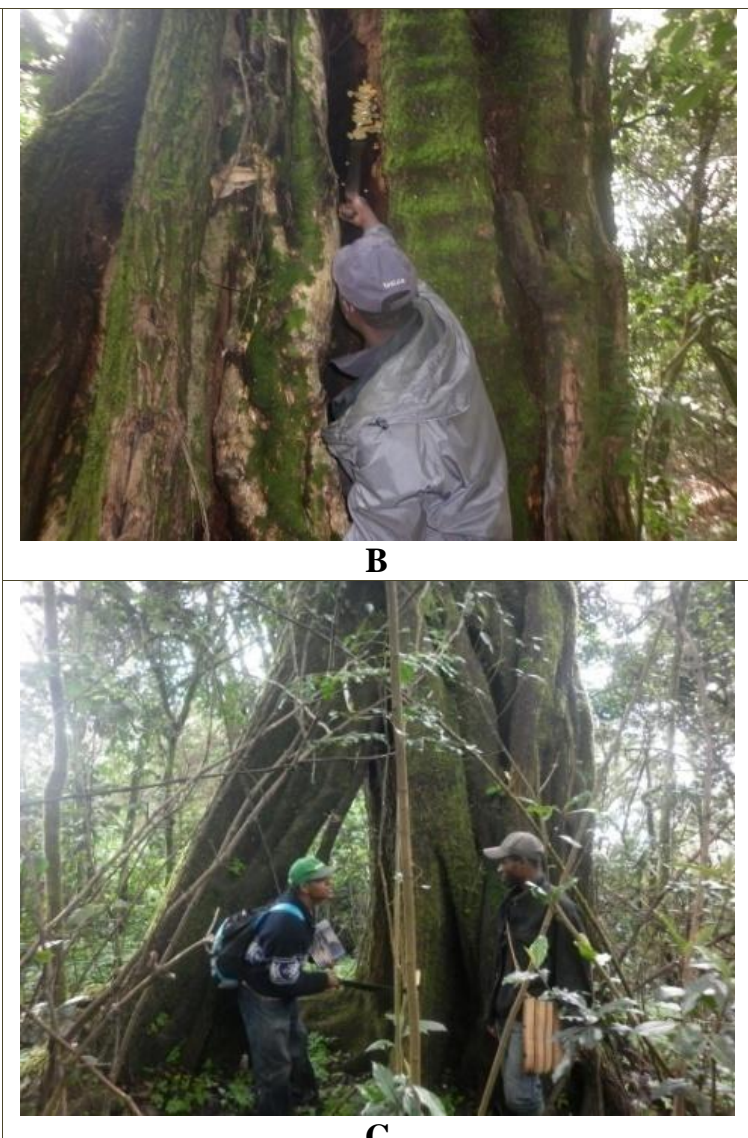

C

Fig. 5-2: Photographs of the widened bases of Syzygium guineense and 2 strangler epiphytes. A. The form and structure of Ficus chlamydocarpa with fluted stem, in the Oku Sacred forest but equally distributed in other Mountain forest of Cameroon and Bioko (Fernando Po). B. Fissured trunck of Syzygium guineense. A native harvesting edible mushrooms from that hollow trunck. C. Form and architecture of a mountain forest Schefflera mannii. Notice the height of the buttress relative to two researchers close by. 
Except for one herbarium specimen identified to the genus level, all others were identified to the level of the species. The more diversified families were the Rubiaceae and Araliaceae with each having four and three species respectively. Seven other families were represented by 2 species only and included Euphorbiaceae, Maesaceae, Melianthaceae, Moraceae, Myrsinaceae, Myrtaceae and Rutaceae. The names of the authors of the species appear in the Appendix 1. To reduce identification bias, three controversial families (Caesalpiniaceae, Fabaceae and Mimosaceae) were grouped as Leguminosae.

Considering the forest structure with respect to tree diameter, $75.8 \%$ i.e. 708 individuals fall under the diameter class $10-30 \mathrm{~cm}, 11.56 \%$ i.e. 108 individuals belonged to diameter class $30-70 \mathrm{~cm}$ and $12.53 \%$ i.e. 118 individuals were identified in the middle interval of 70$230 \mathrm{~cm}$ diameter class. Five individuals of the diameter class of big trees $(220-230 \mathrm{~cm})$ occupied $<1 \%$ of total individuals. Other species such as Syzygium guineense (Myrtaceae) and Schefflera mannii (Araliaceae) recorded 2 individuals each while Schefflera abyssinica recorded only a single individual.

During our survey period, Syzygium guineense was recorded with highest blooming. It reaches very big diameter (Fig. 5-2). But this horizontal development is not followed by the vertical growth. The species doesn't pass $35 \mathrm{~m}$ of height. Schefflera abyssinica and S. mannii were the strangler epiphytes as well as Ficus thonningii that reach the $\mathrm{dbh}$ of $217 \mathrm{~cm}$. The roots of these hemiepiphyte, sometimes lianescentes, descend on the contour of the trunk of the plant host or straight up from some branches. They themself anastomose in an atypical stems of big diameters around the host's trunk that will end up degenerating. The dbh class distribution revealed an inverse-shaped curve (Fig. 6).

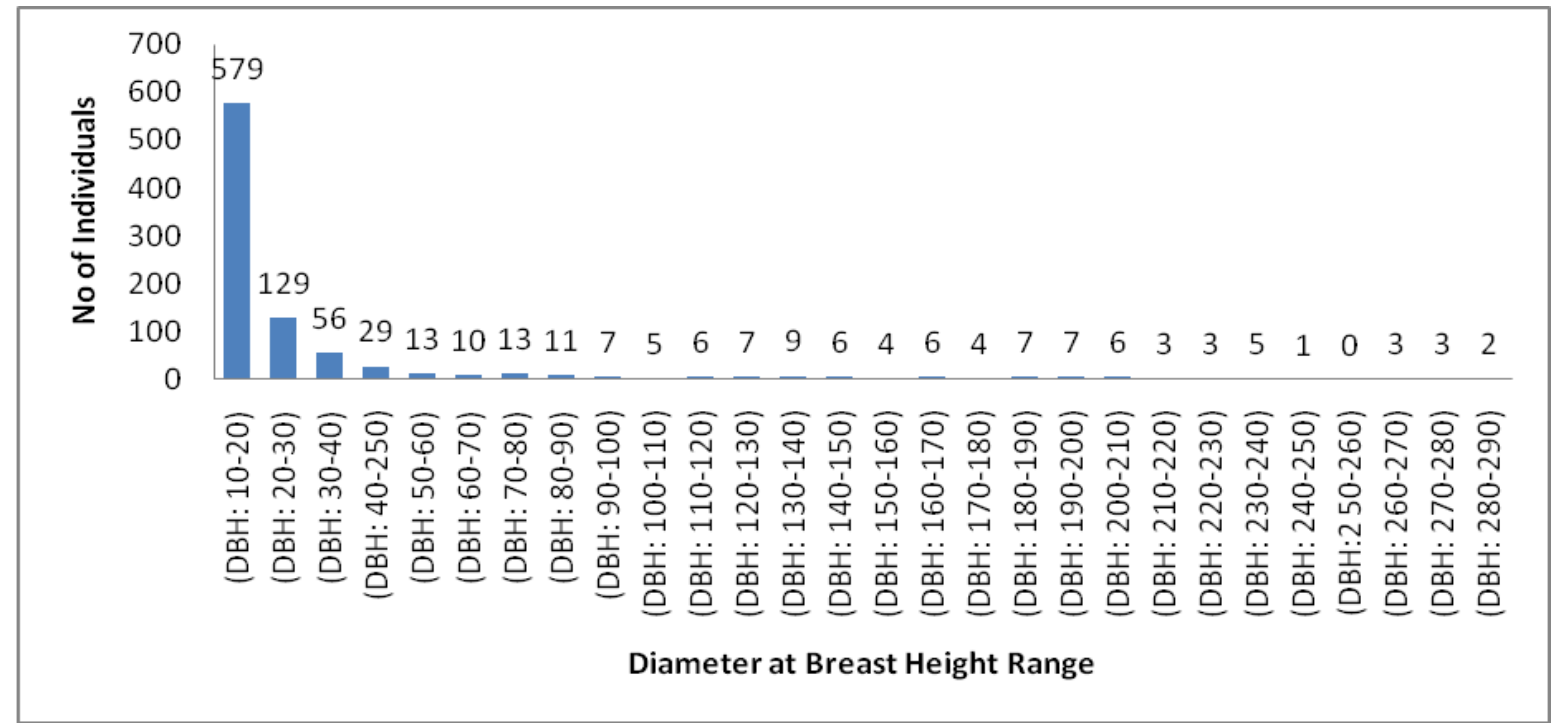

Fig. 6: Distribution of trees in $10 \mathrm{~cm}$ dbh interval size classes. The numbers of recorded individuals are indicated for every size class.

The number of species sampled per plot varied from 17 to 31 with an average of 26.22 species per plot. The species accumulation curve was calculate by the logarythmic equation $\mathrm{y}=6.53 \ln (\mathrm{x})+17.50$ with correlation coefficient $(\mathrm{R}=0.97)$ corresponding to a coefficient of determination, $\mathrm{R}^{2}=0.95$. The curve describes a landing paralel to $\mathrm{X}$ - axis, testifying the reach of the minimal area (Fig. 7).

The species individual curves are drawn for 3 intervals of diameter (Table 2; Fig. 8). The observation of the slope to the origin of the curve shows a faster increasing of the number of lower stratum species. The curve of the woody in $10 \leq \mathrm{dbh}<30 \mathrm{~cm}$ presents a faster growth and describes a landing subparallel to the axis of the abscissas. That lower stratum is always the more diversified. The curve of the superior stratum stays below the other by the number of species, but however passes the one in $30 \leq \mathrm{dbh}<70 \mathrm{~cm}$ by the numbers individuals.

On the same level of sampling effort, for 108 individuals observed in every stratum, the results are presented in Table 3. The lower stratum (woody with $10 \leq \mathrm{dbh}<30 \mathrm{~cm})$ is the more varied with 18 plant species. 


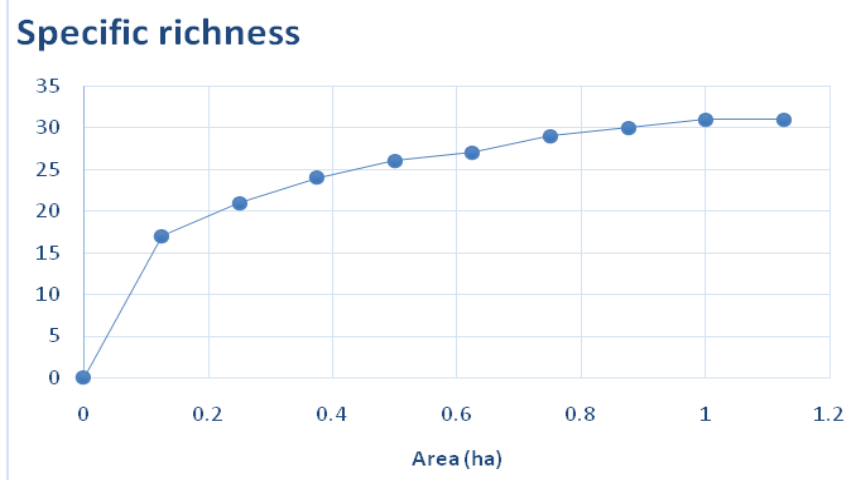

Fig. 7: Species accumulation curve of the Oku sacred forest.

\section{Some spectra of Oku sacred forest}

\section{Phytogeographic affinities}

The floristic fund of the Oku sacred forest shows the abundance of the guinea-Congolese species (more than $54 \%$ of the total species), against $45 \%$ of the large distributed species (Table 4). Among this latter, 12.91\% belong to the group of endemic species of the Cameroonian highlander archipelago, including Bioko, 2850m (ex Fernando Po) (Letouzey, 1985; Stuart and Cheeck, 1998).

Table 2. Diversity of 3 strata (RS: specific richness, N: number of ligneous species whose distribution is observed, ISH: Shannon specific diversity index values and EQ: Pielou equitability index values.

\begin{tabular}{llllll}
\hline Plant strata & diameter classes & RS & N & ISH & EQ \\
\hline Highest stratum & dbh $\geq 70 \mathrm{~cm}$, & 12 & 118 & 2.60 & 0.73 \\
Middle stratum & $30 \leq \mathrm{dbh}<70 \mathrm{~cm}$ & 14 & 108 & 3.7 & 0.81 \\
Lower stratum & $10 \leq \mathrm{dbh}<30 \mathrm{~cm}$ & 28 & 708 & 3.48 & 0.72 \\
\hline
\end{tabular}

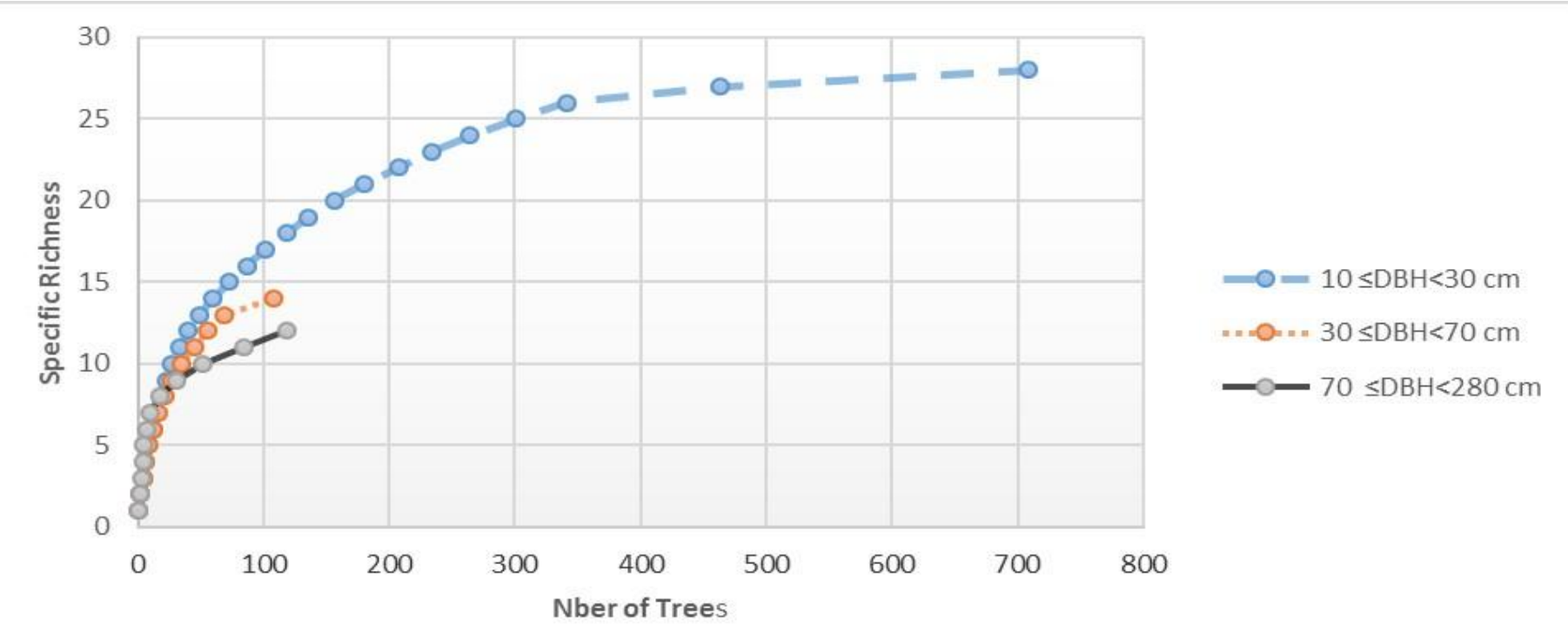

Fig. 8: Species strength accumulation curve of 3 categories of $\mathrm{dbh}(\mathrm{dbh} \geq 70,30$ and $10 \mathrm{~cm})$ on the entirety of the inventory, with respect to each of these categories.

Table 3. Size of the sampling and diversity of 108 woody by stratum (RS: specific richness, N: number of woody species whose distribution is observed, ISH: values of index of specific diversity of Shannon and EQ: values of the index of the Pielou equitability).

\begin{tabular}{llllll}
\hline Strata plantation & Classes of diameter & $\begin{array}{l}\text { Number of } \\
\text { individuals }\end{array}$ & $\begin{array}{l}\text { Number of } \\
\text { species }\end{array}$ & ISH & EQ \\
\hline Highest stratum & $70 \leq \mathrm{dbh}<280 \mathrm{~cm}$ & 108 & 12 & 2.60 & 0.73 \\
Middle stratum & $30 \leq \mathrm{dbh}<70 \mathrm{~cm}$ & 108 & 14 & 3.07 & 0.81 \\
Lower stratum & $10 \leq \mathrm{dbh}<30 \mathrm{~cm}$ & 108 & 18 & 3.97 & 0.95 \\
\hline
\end{tabular}


Table 4. Spectra of phytogeographic groups

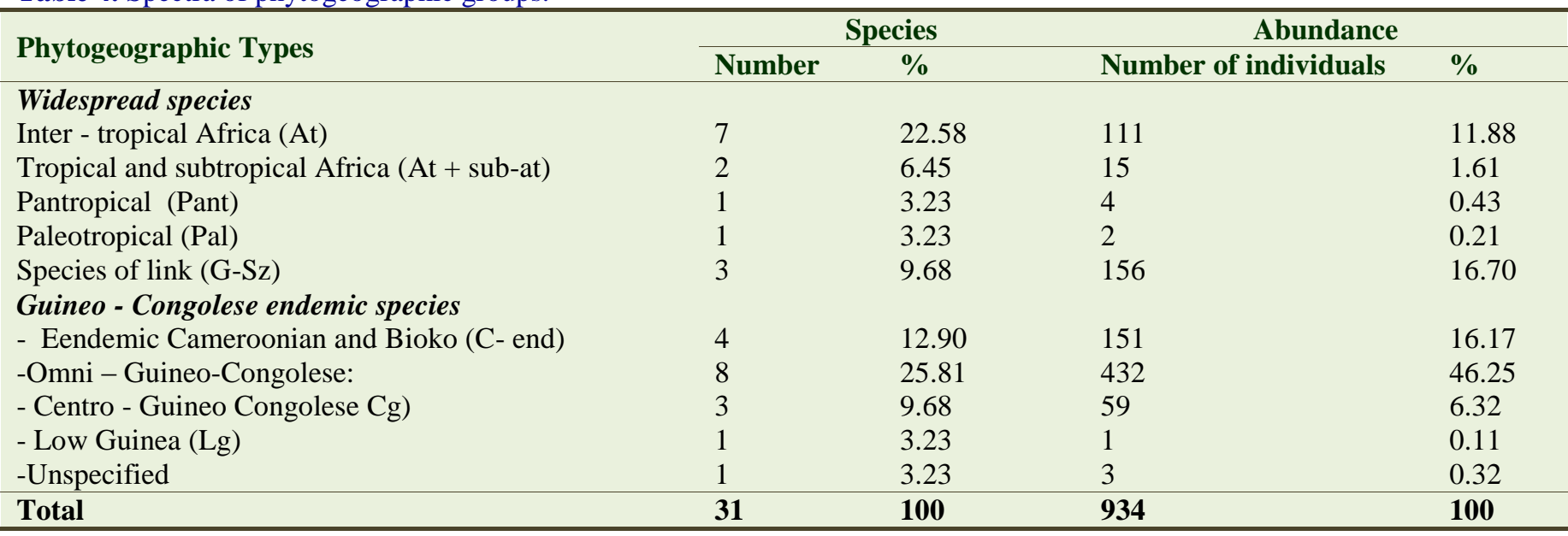

\section{Spectra of the altitudinal variations}

The regroupings by altitudinal floor of the specific whole give the absolute values and the centesimal proportions reported in Table 5. For the aspects of forestry and altitudinal successions, the categories are deducted of the temperaments of the species. Only the intermediate combinations between two successive types of the pressure gradient (and non-disconnected) are generally feasible for species of link (Senterre, 2005; Noumi, 2013) (Table 5). The highlander groupings (5 and 6 of the Table 4) showed a total of 15 species $(48.38 \%)$, with $73.34 \%$ of individuals. They are followed by the submontane groupings that totalize 9 species, either $29 \%$ of the set of the species represented by $10.28 \%$ of individuals.

\section{The floristic tendency of the species}

The data of the Table 5 (columns 2) revalued according to the number of species, gave a total of 41 altitudinal antecedents (Table 6). The strong floristic tendency of the species are Afro highlander; 53.66\% of the species. The floristic tendency of low and middle altitudes species $(17.07 \%)$ with a weak abundance (14.88\%). Two species can bring up in the Afro subalpin floor.

Table 5. Spectra of the altitudinal floors or altitudinal antecedents.

\begin{tabular}{|c|c|c|c|c|c|c|}
\hline $\begin{array}{l}\text { Species bound to the Antecedents } \\
\text { altitudinaux }\end{array}$ & $\begin{array}{l}\text { Altitudinal } \\
\text { antecedents }\end{array}$ & $\begin{array}{l}\text { Altitudes } \\
\text { (m) }\end{array}$ & $\begin{array}{l}\text { Species } \\
\text { Number }\end{array}$ & $\%$ & $\begin{array}{l}\text { Abundance } \\
\text { Individuals } \\
\text { number }\end{array}$ & $\%$ \\
\hline $\begin{array}{l}\text { 1. Species typically of low and middle } \\
\text { altitudes }\end{array}$ & $\mathrm{Bm}$ & 1 à 1000 & 4 & 12.90 & 112 & 11.99 \\
\hline $\begin{array}{l}\text { 2. Species connexion low and middle } \\
\text { /submontane altitudes }\end{array}$ & $\mathrm{Bmt} / \mathrm{Sm}$ & & 3 & 9.68 & 41 & 4.39 \\
\hline 3. Species typically submontane & $\mathrm{Sm}$ & 1000 à 2000 & 4 & 12.90 & 73 & 7.82 \\
\hline $\begin{array}{l}\text { 4. Species of connexion submontane / } \\
\text { Afro highlander }\end{array}$ & $\mathrm{Sm} / \mathrm{Mi}$ & & 5 & 16.13 & 23 & 2.46 \\
\hline $\begin{array}{l}\text { 5. Species typically Afro highlander, with } \\
\text { strong hygrometry (Afro highlander } \\
\text { floor) }\end{array}$ & $\mathrm{Mi}$ & 2000 à 3000 & 13 & 41.94 & 655 & 70.13 \\
\hline $\begin{array}{l}\text { 6. Species of connexion Afro highlanders } \\
\text { / Afro subalpin, with weak hygrometry, }\end{array}$ & $\mathrm{Mi} / \mathrm{Ms}$ & & 2 & 6.45 & 30 & 3.21 \\
\hline $\begin{array}{l}\text { 7. Species typically Afro subalpin (weak } \\
\text { humidity) }\end{array}$ & Ms & $\begin{array}{l}3000 \text { à } 4000 \\
\text { (Cameroon } \\
\text { mount) }\end{array}$ & & & & \\
\hline Total & & & 31 & 100 & & 100 \\
\hline
\end{tabular}


Table 6. Spectra of the groups of the floristic altitudinal tendencies and their species, to the different floors.

\begin{tabular}{|c|c|c|c|c|}
\hline \multirow[b]{2}{*}{ Floristic altitudinal tendencies } & \multicolumn{2}{|c|}{ Species } & \multicolumn{2}{|c|}{ Abundance } \\
\hline & Number & $\%$ & $\begin{array}{l}\text { Individuals } \\
\text { number }\end{array}$ & $\%$ \\
\hline Floristic tendency of low and middle altitude $(\mathrm{Bm})$ & 7 & 17.07 & 153 & 14.88 \\
\hline Floristic tendency f submontane $(\mathrm{Sm})$ & 12 & 29.27 & 137 & 13.33 \\
\hline $\begin{array}{l}\text { Floristic tendency Afro highlander (strong hygrometry) (floor Afro } \\
\text { highlander) (Mi) }\end{array}$ & 20 & 48.78 & 708 & 68.87 \\
\hline Floristic tendency Afro subalpine (weak humidity) (Ms) & 2 & 4.88 & 30 & 2.92 \\
\hline Total & 41 & 100 & 1028 & 100.00 \\
\hline
\end{tabular}

Table 7. Spectra of the ecosociologic groups.

\begin{tabular}{|c|c|c|c|c|}
\hline \multirow[b]{2}{*}{ Ecosociologic groups } & \multicolumn{2}{|c|}{ Species } & \multicolumn{2}{|c|}{ Abundance } \\
\hline & Number & $\%$ & $\begin{array}{l}\text { Number } \\
\text { Individuals }\end{array}$ & $\%$ \\
\hline Fic - Ficalhoeto-Podocarpetalia (Lebrun and Gilbert, 1954) & 13 & 41.94 & 677 & 72.48 \\
\hline Gar - Garcinietalia (Noumi, 1998) & 4 & 12.90 & 64 & 6.85 \\
\hline Gil - Gilbertiodendretalia dewevrei (Lebrun and Gilbert, 1954) & 3 & 9.68 & 47 & 5.03 \\
\hline Mus - Musango-Terminalietea (Lebrun and Gilbert, 1954) & 2 & 6.45 & 44 & 4.71 \\
\hline Pip - Piptadenio-celtidetalia (Lebrun and Gilbert, 1954) & 1 & 3.22 & 42 & 4.49 \\
\hline Pol - Polyscietalia fulvae (Lebrun and Gilbert, 1954) & 5 & 16.13 & 27 & 2.89 \\
\hline Str - Strombosio-Parinarietea (Lebrun and Gilbert, 1954) & 3 & 9.68 & 33 & 3.53 \\
\hline Total & 31 & 100 & 934 & 100 \\
\hline
\end{tabular}

The exam retailed of the types of ecosociologic groups of the whole specific (Table 7) gave the groups and values encoded consigned in the Table 8 . The highlander taxons (Fic and Pol) reach $58.06 \%$ of the total species and the plants (Gil, Mus and Pip) 19.3\%.

Any phytosociologic grouping obeys to own mesologic parameters or at least climatic. The different phytosociologic groupings established (Table 8), reveal a telescoping of different climatic parameters in the Oku sacred forest, so much so that one would qualify them of syngenetic groupings (formed together; whose birth is common).

\section{Floristic composition}

Family level- Nineteen families were recorded in the sampling 1.125-ha. The 10 most important families for each relative parameter and FIV are listed (Table 9). The complete results for every family are given in Appendix 2.

Table 8. Phytogeographic and phytosociologic affinities of the identified species of the Oku sacred forest sampling.

\begin{tabular}{|c|c|c|c|c|c|c|}
\hline Altitudinal strata & \multicolumn{3}{|c|}{ Lowlands stratum } & $\begin{array}{l}\text { Submontane } \\
\text { stratum }\end{array}$ & \multicolumn{2}{|c|}{$\begin{array}{l}\text { Lower montane stratum (high } \\
\text { hygrometry) }\end{array}$} \\
\hline $\begin{array}{l}\text { Phytogeographic } \\
\text { affinities }\end{array}$ & \multicolumn{3}{|l|}{$\mathrm{Bm}, \mathrm{Bm} / \mathrm{Sm}$} & Sm, Sm/Mi & \multicolumn{2}{|l|}{ Mi, Mi/Ms } \\
\hline \multirow[b]{2}{*}{$\begin{array}{l}\text { Phytosociologic } \\
\text { groups }\end{array}$} & \multirow[b]{2}{*}{$\begin{array}{l}\text { Musango- } \\
\text { Terminalietea } \\
\text { (Lebrun and } \\
\text { Gilbert, 1954) }\end{array}$} & \multirow[b]{2}{*}{$\begin{array}{l}\text { Piptadenio- } \\
\text { celtidetalia } \\
\text { Lebrun and } \\
\text { Gilbert, } 1954\end{array}$} & \multicolumn{4}{|c|}{$\begin{array}{l}\text { Strombosio-Parinarietea (Lebrun and Gilbert, 1954): 3species (9.68\%); } 33 \\
\text { individuals }(3.53 \%)\end{array}$} \\
\hline & & & $\begin{array}{l}\text { Gilbertiodendretalia } \\
\text { dewevrei (Lebrun } \\
\text { and Gilbert, 1954) }\end{array}$ & $\begin{array}{l}\text { Garcinietalia } \\
\text { (Noumi, 1998) }\end{array}$ & $\begin{array}{l}\text { Ficalhoeto- } \\
\text { Podocarpetalia } \\
\text { (Lebrun and } \\
\text { Gilbert, 1954) }\end{array}$ & $\begin{array}{l}\text { Polyscietalia } \\
\text { fulvae (Lebrun } \\
\text { and Gilbert, } \\
\text { 1954) }\end{array}$ \\
\hline $\begin{array}{l}\text { Number of species } \\
\text { (and percentage) }\end{array}$ & $2(6.45 \%)$ & $2(6.45 \%)$ & $2(6.45 \%)$ & $4(12.90 \%)$ & $13(41.94 \%)$ & $5(16.13 \%)$ \\
\hline $\begin{array}{l}\text { Number of } \\
\text { individuals (and } \\
\text { percentage) }\end{array}$ & $44(4.71 \%)$ & $43(4.60 \%)$ & $46(4.93 \%)$ & $64(6.85 \%)$ & $677(72.48 \%)$ & $27(2.89 \%)$ \\
\hline
\end{tabular}


Table 9. Families with highest values of relative diversity, relative density, relative dominance and FIV in decreasing order. Families that do not rank among the ten most important in FIV value appear in bold type.

\begin{tabular}{lclllclc}
\hline Relative diversity & {$[\mathbf{x ~ 1 0 0 \%}]$} & Relative density & {$[\mathbf{x ~ 1 0 0 \%}]$} & Relative dominance & [x 100\%] & FIV & [x 300\%] \\
\hline Rubiaceae & 12.90 & Meliaceae & 30.41 & Araliaceae & 34.65 & Araliaceae & 49.15 \\
Araliaceae & 9.68 & Monimiaceae & 14.56 & Myrtaceae & 21.77 & Myrtaceae & 39.03 \\
Euphorbiaceae & 6.45 & Myrtaceae & 10.81 & Leguminosae & 10.82 & Meliaceae & 37.88 \\
Maesaceae & 6.45 & Rubiaceae & 10.28 & Moraceae & 9.65 & Rubiaceae & 24.64 \\
Melianthaceae & 6.45 & Melianthaceae & 6.21 & Buddlejaceae & 9.17 & Monimiaceae & 19.48 \\
Moraceae & 6.45 & Araliaceae & 4.82 & Meliaceae & 4.25 & Leguminosae & 18.54 \\
Myrsinaceae & 6.45 & Leguminosae & 4.50 & Melianthaceae & 2.98 & Moraceae \\
Myrtaceae & 6.45 & Apocynaceae & 4.28 & Monimiaceae & 1.70 & Melianthaceae & 15.39 \\
Rutaceae & 6.45 & Buddlejaceae & 3.00 & Sapindaceae & 1.46 & Buddlejaceae & 15.39 \\
Apocynaceae & 3.23 & Convolvulaceae & 2.14 & Rubiaceae & 1.45 & Rutaceae & 8.54 \\
\hline
\end{tabular}

For each family the numbers of individuals and species; the basal area, the values of diversity, density and dominance relative as well as those of FIV are given (Appendix 2). A diagram represents the weight of each of the three factors composing the FIV of the sampling on 1.125-ha, for the 10 families (in decreasing order) whose FIV values are the most important (Fig. 9).

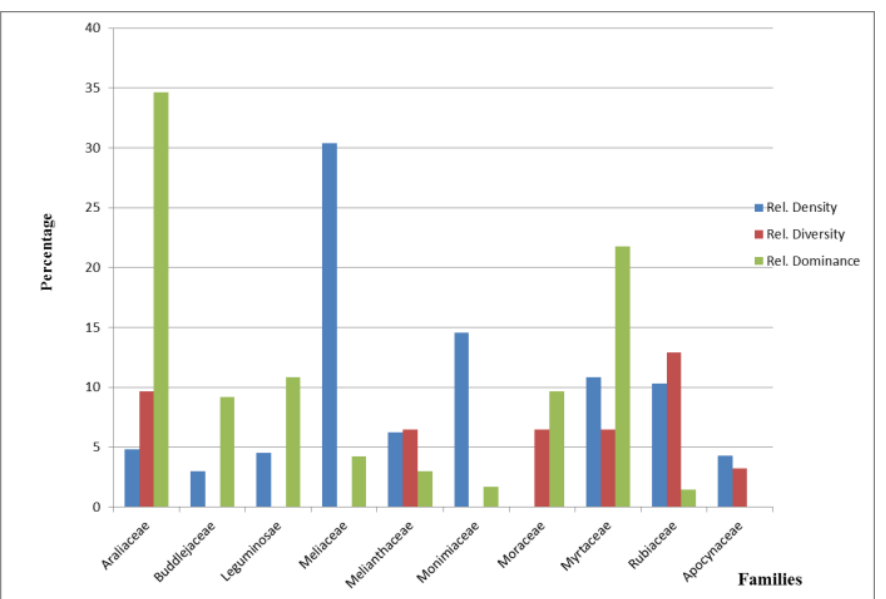

Fig. 9: Relative diversity, Relative density and Relative Dominance of the ten most important families in FIV.

Regarding relative density, the 4 most abundant families are, Meliaceae, Monimiaceae, Myrtaceae and Rubiaceae, regrouping $66.06 \%$ of all recorded individuals. The density of the Meliaceae exceeds $30 \%$ whereas the $5^{\text {th }}$ species in density doesn't reach $7 \%$. The families with the highest values in dominance are Araliaceae Myrtaceae, Leguminosae, Moraceae and Buddlejaceae. Together they reach $86.06 \%$ of dominance of all trees counted in the summary. The 10 richest families are specifically Rubiaceae, Araliaceae, Euphorbiaceae, Maesaceae, Melianthaceae, Moraceae, Myrsinaceae, Myrtaceae, Rutaceae and Apocynaceae. The relative diversity of Rubiaceae (4 species) represents $12.9 \%$ of the total species diversity of the sampling. Ten families are represented by a single species, 7 by 2 species, 1 by 3 species and 1 by 4 species (Appendix 2).
With regard to Family Importance Value (FIV), Araliaceae are the most important family in the sampling with a FIV of 49.15. They also have the highest relative dominance and relative diversity, and occupy the $6^{\text {th }}$ rank in relative density values. When comparing FIV and the 3 relative values of the ten most important families, only Araliaceae, Myrtaceae, Rubiaceae and Melianthaceae appeared among the first ten families for all parameters, and Meliaceae Monimiaceae, Leguminosae, Moraceae, Buddlejaceae for 2 parameters. Rutaceae are tenth in FIV due to their relative diversity. Rubiaceae are $1^{\text {st }}$ in relative diversity but they drop to the position $4^{\text {th }}$ in FIV because of their low relative density and dominance. Considering relative dominance, Sapindaceae have some appreciated values and account for $1.46 \%$ of the total basal area, but are represented by only one species and a few individuals respectively. Thus that family is not among the ten families with the highest FIV; so as Apocynaceae, 8th in relative density and $10^{\text {th }}$ in relative diversity. Euphorbiaceae, Maesaceae Myrsinaceae have the $3^{\text {th }}$ position in relative diversity $(6.45 \%)$ and the weak values in the two other parameters, thus, these families are not among the ten families with the highest FIV.

Specific level - We recorded thirty-one species in the sampling. The authors of scientific name appear in Appendix 1. Table 10 lists the ten most important species in each relative parameter. The values of each parameter for the ten species with the higher IVI are represented in Table 5. Appendix 3 gives the results for all species. A small group of species dominates the plot: 3 species Carapa grandiflora, Xymalos monospora and Syzygium guineense $(0.096 \%$ of the total number of species) account for $53.64 \%$ of all trees. The majority of species $(32.25 \%)$ are represented by less than 5 individuals: 2 species are represented by 2 individuals, and 3 species $(0.096 \%)$ are represented by a single individual. Regarding relative dominance, less than $1 \%$ of the species contribute $65.22 \%$ of total basal area. 
Table 10. Species with highest values of relative frequency, relative density, relative dominance and IVI in decreasing order. Species that do not rank among the ten most important in IV I value appear in bold characters.

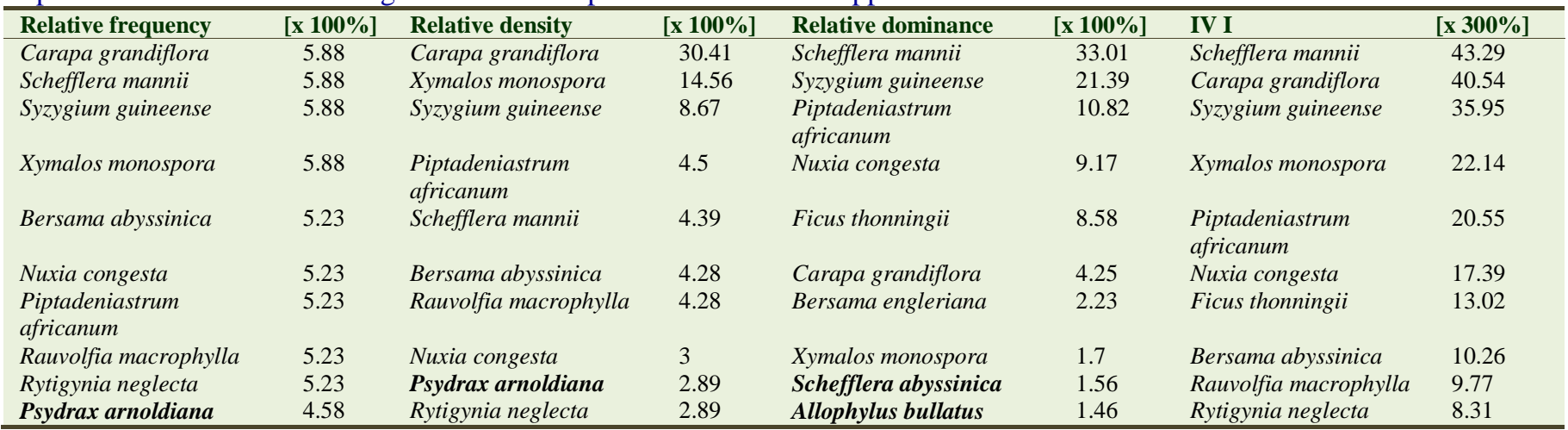

High dominance can be achieved by a great number of small trees or by a few large trees. Allophylus bullatus is $10^{\text {th }}$ in relative dominance but drops to $15^{\text {th }}$ position in relative density. Psydrax arnoldiana is $9^{\text {th }}$ in relative density, but it is $18^{\text {th }}$ in relative dominance as Rytigynia neglecta. Thus, in spite of the $10^{\text {th }}$ rank occupied in relative frequency, it is not among the first 10 species with the strongest values in IVI (Fig. 10).

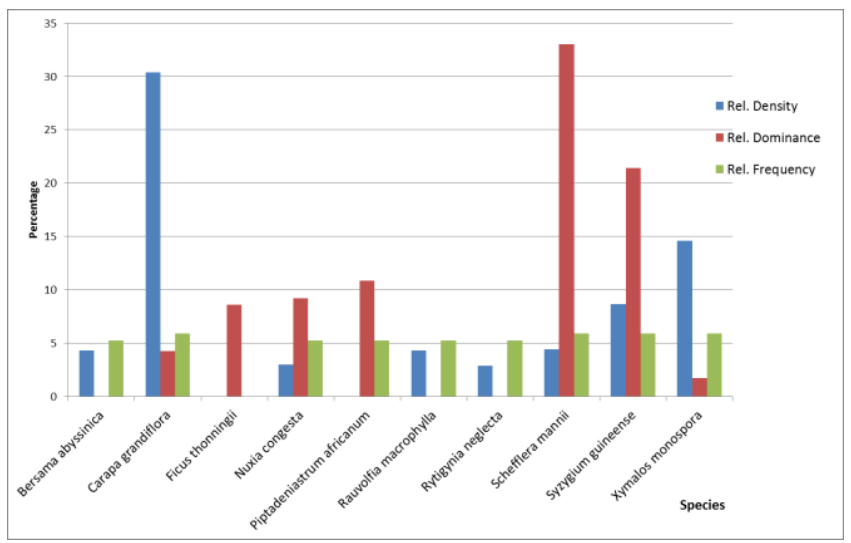

Fig. 10: Relative frequency, relative density, and relative dominance of the ten most important species in IVI.

\section{Discussion}

The comparisons between the data of this survey and those of other dense forests of Africa, Madagascar and Neotropic region are based on the floristic and structural, quantitative and qualitative parameters. The main aim was to determine the parameters that make the differences and those that bring them closer, to highlight the features closed to the Oku highlander sacred forest.

\section{Oku sacred forest structure}

The species-area accumulation curve for the plot is drawn and compared to those of some samplings of central Africa (Fig. 11). In any case, the expression of the study area shows quantitatively low data. It follows a classical accumulation curve. In the two last consecutive quadrats, any new species was encountered making it easy to determine that one ha is satisfactory for a fully representative sample for the forest. In fact it is observable in the accumulation curve. Nevertheless in the other central highlander African forests, new species always occur in spite of the altitude and of the inventoried surface. One can presume that in this study, 1-ha surface is suitable for the study (D'Amico and Gautier, 2000; Nusbaumer et al., 2005).

The density of 934 trees $\geq 10 \mathrm{~cm}$ dbh per 1.125 -ha, or 830 per hectare, is within the range of 167 to 1947 individuals per hectare reported by (Gentry, 1982) for Neotropical forests sampled by different methods, and the range of 554 to 1269 trees/ha $(\mathrm{dbh} \geq 10 \mathrm{~cm})$ (Table 11) recorded in a series of plots set high elevation rainforests, in different hills and mountains of Cameroon.

The comparison with inventoried trees of tropical rainforests sampled in various continents shows that tree density seems to have a high similar range of variation in the mountain forests throughout the world (Mohandass and Davidar, 2009) but, no matter the altitude (Table 11). The classes of diameters go from 10 to $230 \mathrm{~cm}$ (Figs. 12A, 12B). Some more modest dimensions has been observed in the forests of the highlands: $10-135 \mathrm{~cm}$ in the Kouoghap sacred submontane forest, $10-120 \mathrm{~cm}$ in the Manengouba montane forest (Noumi, 2012 and 2013), in the Messa submontane forest (Tagne, 2007) the big diameters are between 200 and $230 \mathrm{~cm}$. The trees with diameters equal or superior to those of the Oku sacred forest are observed in the temperate countries; 6 to $8 \mathrm{~m}$ for Sequoiadendron giganteum (Lindley) J. Buchholz, 1939 (Cupressaceae) (Fig. 12C); the most imposing specimen is 'General Sherman', in the national Park of 
Redwood (United States) (Robert, 2001) ; 2 to $3 \mathrm{~m}$ for Pseudotsuga menziesii (Mirb.) Free, 1950 (Pinaceae) (Mailleux et al., 2007); $2 \mathrm{~m}$ for Abies nordmanniana (Steven) Spach, 1841 (Pinaceae) (Julve, 1998).

The stability of the forest protected from the anthropisation by the customary rules permitted the development of the epiphytes stranglers trees, in terrestrial trees $(13 \%$ of the species) with a stem built from top to bottom all around of the trunk of the plant host. This one degenerates and let in place the strangler's atypical stem, fluted, large and hollow. Among these last one has in the Oku sacred forest 2 Araliaceae (Schefflera abyssinica and Schefflera mannii) and 2 Moraceae (Ficus chlamydocarpa and Ficus thonningii) whose dbhs reach $2 \mathrm{~m}$ and more.

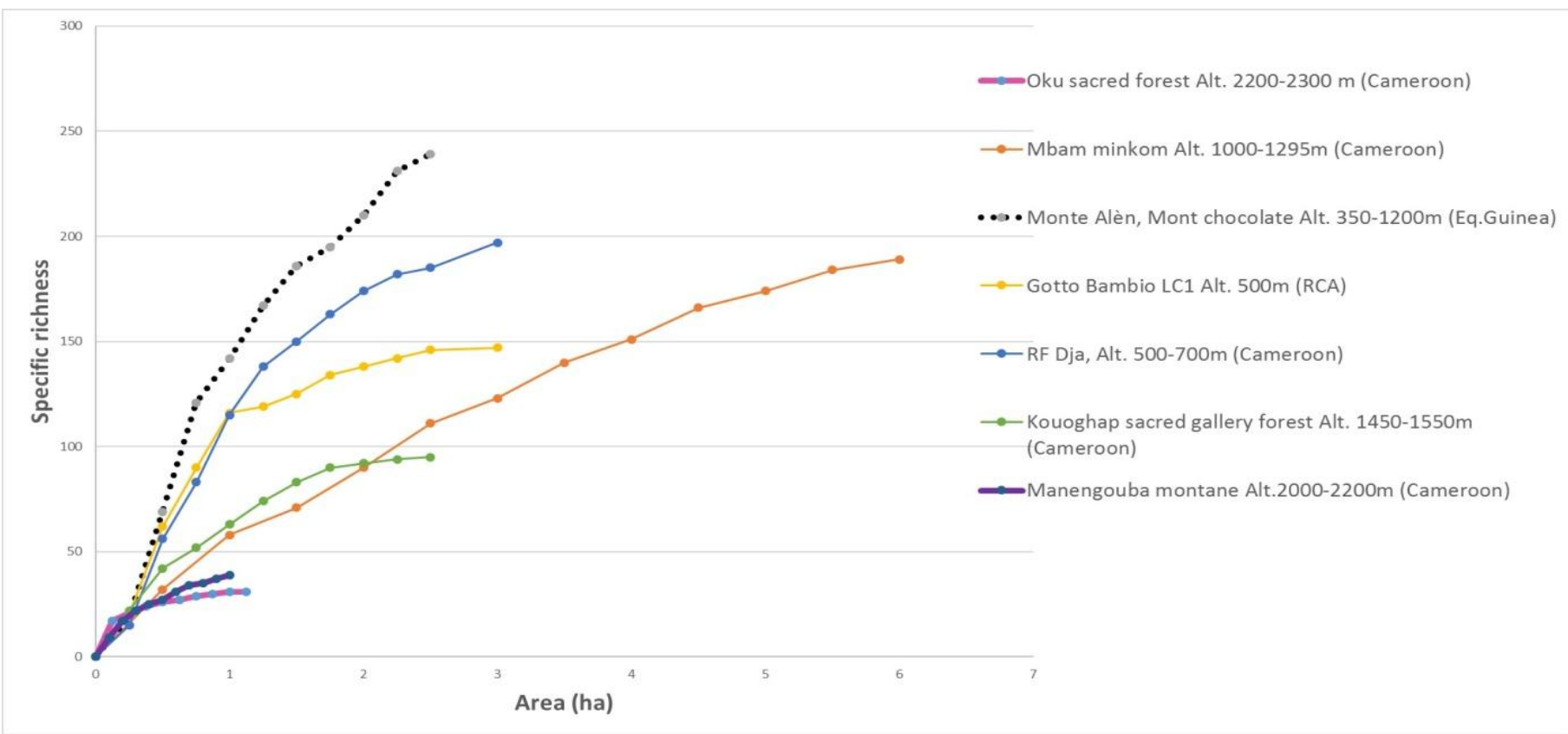

Fig. 11: Species-area accumulation curve of the 1.125-ha plot in the Oku highlander forest (each sub-unit is represented by $50 \mathrm{x} 25$ $\mathrm{m}=0.125 \mathrm{ha}$ ) and 6 species-area accumulation curves achieved in Atlantic central Africa; Gotto, Bambio (Lejoly, 1996); Monte Alèn (Van Reeth, 1997); Dja (Sonke, 1998); Kouoghap (Noumi, 2012); Manengouba (Noumi, 2013); Mbam minkom (Noumi, 2015); Oku (present study, the lower curve).

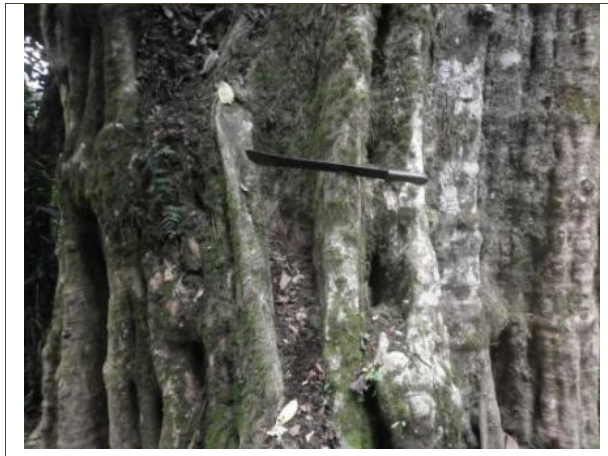

A machete on a malformed, bumpy and fluted stem carrying the hollows, of Syzygium guineense (Myrtaceae); $\mathrm{dbh}=$ $227 \mathrm{~cm}$.

(A)

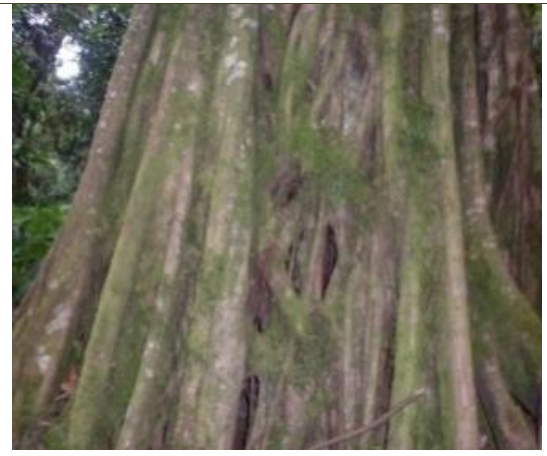

Small fluted going up the irregular stem of Ficus thonningii (Moraceae); $\mathrm{dbh}=213 \mathrm{~cm}$.

(B)

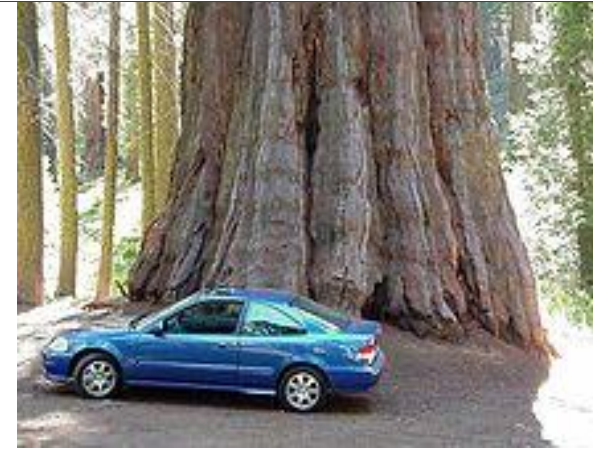

A car owing a foot of Sequoiadendron giganteum. National park of Redwood (United States); $\mathrm{dbh}=600 \mathrm{~cm}$ about.

(C)

Fig. 12: Some specimens of big diameters stems in the Oku sacred forest facing the one of Sequoiadendron giganteum the biggest tree of the world in volume. The gigantic redwood champion is the "General Sherman" with a volume of $1486 \mathrm{~m}^{3}$, a circumference of $31.3 \mathrm{~m}$ (diameter $=9.97 \mathrm{~m})$ and a height of $83.8 \mathrm{~m}$. 
The structure the Oku sacred mountain forest is in a high range as the montane Shola forests of the Nilgiris (Mohandass and Davidar, 2009). The basal area (230.64 $\mathrm{m}^{2} / 1.125$-ha or $205.02 \mathrm{~m}^{2} / \mathrm{ha}$ ) is more elevated than the value reported in the highlander forests (Table 12) and those reported by Mori et al. (1983) for five moist lowland neotropical forests (ranging from 21.5-53.0 $\mathrm{m}^{2} /$ ha) sampled by the point centered quarter method (Cottam and Curtis, 1956). Basal areas have also been found in other lowland rainforests of Madagascar sampled using the permanent 1-ha plot method: 34.1 $\mathrm{m}^{2} / \mathrm{ha}$ at Andohahela (Rakotomalaza and Messmer, 1999), and a range of 19.0 to $38.9 \mathrm{~m}^{2} / \mathrm{ha}$ in ten different eastern lowland forests (Rabevohitra et al., 1996), or in African lowland rainforest of : $19.2 \mathrm{~m}^{2} / \mathrm{ha}$ in Cameroon (Lejoly, 1996) ; $42.32 \mathrm{~m}^{2} / \mathrm{ha}$ in Benin (Sokpon, 1995) ; $30.82 \mathrm{~m}^{2} /$ ha in Côte-d'Ivoire (Nusbaumer et al., 2005). In this study the value of the basal area and the distribution of the diameter classes observed are typical of a forest in good state of conservation (Rollet, 1979). The forest remains always in the state of growth, due to its mesologic characters (Lebrun and Gilbert, 1954). The individuals of the montane ombrophile species (Syzygium guineense and Zanthoxylum heitzii) gain dimension.

\section{Floristic composition}

The floristic list is composed of 31 species with one not identified (Appendix 1) from which are derivate 27 genera and 19 families. The nomenclature follows Lebrun and Stork (1991-1997). Family level: In the plot sampled, more than $55 \%$ of all trees are represented by 3 families (Meliaceae, Monimiaceae and Myrtaceae). According to Rabevohitra et al. (1996), 4, 5 or 6 families always represent more than $50 \%$ of total trees in littoral forests along Madagascar's East coast. Table 13 shows that in Oku sacred forest and others highlander forests inventories in Guinean region and Madagascar, Meliaceae Monimiaceae, Myrtaceae and Rubiaceae are frequently among the ten most abundant families. Melianthaceae and Buddlejaceae (former Loganiaceae) seem to be the only numerically important families of the Oku sacred forest that do not occur in the first ten positions in other lowland and highland plots in Guinean region and Madagascar.

Table 11. Number of trees per hectare $(\mathrm{dbh} \geq 10 \mathrm{~cm})$ in Oku sacred rainforest and in lowland rainforests sites in Africa, Madagascar and Neotropic regions, by decreasing density.

\begin{tabular}{|c|c|c|c|}
\hline Sites & Countries & References & $\begin{array}{l}\text { Number } \\
\text { trees/ha }\end{array}$ \\
\hline \multicolumn{4}{|c|}{ Highland forests } \\
\hline Kouoghap sacred forest & Cameroon & Noumi (2012) & 1269 \\
\hline Shola montane evergreen forest & Nilgiri, India & Mohandass and Davidar (2009) & 832 \\
\hline Oku sacred forest & Cameroon & Present study & 830 \\
\hline Manengouba forest (Mbouroukou) & Cameroon & Present study & 763 \\
\hline Mbam minkom submountain forest & Cameroon & Noumi (2015) & 554 \\
\hline Messa submountain forest & Cameroon & Tagne (2007) & 1008 \\
\hline Kupe & Cameroon & Tchoua (2014) & 1184 \\
\hline Kala submountain forest & Cameroon & Madiapevo (2008) & 2107 \\
\hline \multicolumn{4}{|c|}{ Lowland forests } \\
\hline Andranomintina (plot 1), & Madagascar & Rabevohitra et al. (1996) & 1223 \\
\hline Yasuni (unflooded forest), & Ecuator & Balslev et al. (1987) & 728 \\
\hline Lowland rainforest in Manongarivo & Madagascar & D'Amico and Gauthier (2000) & 728 \\
\hline Yapo (unfloodplain forest), & Côte d'Ivoire & Corthay (1996) & 649 \\
\hline Alto Ivon, & Bolivia & Boom (1986) & 649 \\
\hline Forest of Ngotto & Centrafrican Republic & Lejoly (1995) & 549 \\
\hline Forestry Reserve of Dja (Alat 1.7) & Cameroon & Sonké (1998) & 513 \\
\hline $\begin{array}{l}\text { Forest with Cleistopholis patens and } \\
\text { Ficus mисиso }\end{array}$ & Benin & Sokpon (1995) & 494 \\
\hline Oveng & Gabon & Reitsma (1988) & 485 \\
\hline Jenaro Herrera & Peru & Spichiger et al. (1996) & 482 \\
\hline Bees forest & Gabon & Gesnot (1994) & 458 \\
\hline Yasuni (floodplain forest), & Ecuator & Balslevet al. (1987) & 417 \\
\hline Classified forest of Scio & Côte d'Ivoire & Nusbaumer et al. (2005) & 413 \\
\hline Lopé (site 1) & Gabon & White (1992) & 304 \\
\hline National Park of Odzala (layon Andzoyi) & Congo & Lejoly (1996) & 294.7 \\
\hline
\end{tabular}


Table 12. Basal area/ha in the Oku sacred forest and other highland, lowland rainforests altitudes, in Africa and other areas, in decreasing dominance.

\begin{tabular}{|c|c|c|c|}
\hline Sites & Countries & References & Basal area $\left(\mathrm{m}^{2}\right)$ \\
\hline \multicolumn{4}{|c|}{ Highland forests } \\
\hline Oku sacred forest & Cameroon & Present study & 205.02 \\
\hline Kala submountain,forest & Cameroon & Madiapavo (2008) & 124 \\
\hline Kouoghap sacred forest & Cameroon & Noumi (2012) & 90.36 \\
\hline Manengouba forest (Mbouroukou) & Cameroon & Noumi (2013) & 61.69 \\
\hline Mbam minkom submountain forest & Cameroon & Noumi (2015) & 54.36 \\
\hline Messa submountain forest & Cameroon & Tagne (2007) & 82.13 \\
\hline Shola montane evergreen forest & Nilgiri, India & Mohandass and Davidar (2009) & 53.55 \\
\hline \multicolumn{4}{|c|}{ Lowland forests } \\
\hline $\begin{array}{l}\text { Cleistopholis patens and Ficus mucuso } \\
\text { forest }\end{array}$ & Benin & Sokpon (1995) & 42.3 \\
\hline Yapo classified forest & Côte-d'Ivoire & Corthay (1996) & 40.0 \\
\hline Dja Forestry Reserve (Alat 1.7) & Cameroon & Sonké (1998) & 34.2 \\
\hline Yasuni (unflooded forest) & Ecuator & Balslev et al. (1987) & 33.7 \\
\hline Scio Classified forest & Côte d'Ivoire & Nusbaumer et al. (2005) & 30.82 \\
\hline Andranomintina (plot 1) & Madagascar & Rabevohitra et al. (1996) & 27.9 \\
\hline Andranomintina (plot 2) & Madagascar & Rabevohitra et al. (1996) & 25.3 \\
\hline Jenaro Herrera & Peru & Spichiger et al. (1996) & 22.6 \\
\hline Manongarivo & Madagascar & D'Amico and Gauttier (2000) & 22.4 \\
\hline
\end{tabular}

Table 13. The ten most abundant families in Oku sacred forest and other African and Malagasy forests (altitudes available). Families among the ten most abundant in at least 6 plots appear in bold type.

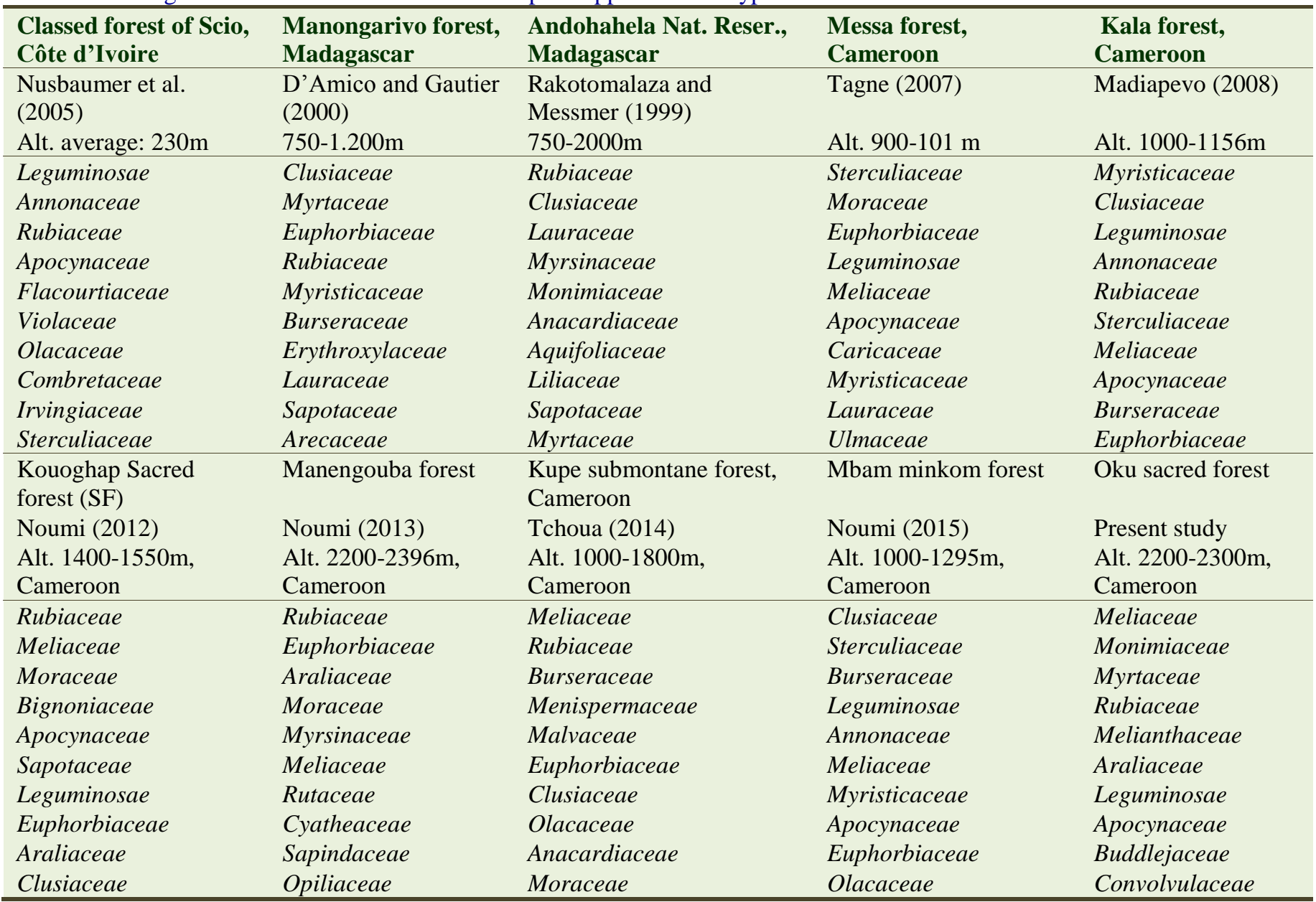


Family composition of highland forest of Cameroon tends to be similar. 14 families (Araliaceae, Burseraceae, Clusiaceae, Euphorbiaceae, Leguminosae, Maesaceae, Meliaceae, Melianthaceae, Monimiaceae, Myrtaceae, Rubiaceae, Rutaceae, Sapotaceae and Sterculiaceae) contribute half of the species to many samples in highland tropical forests in Cameroon. At least eight of these families are always among the ten richest species in Africa and Madagascar as well. In the highland Oku sacred forest, 8 families contribute to $85.87 \%$ of the species richness on 1.125-ha plot (Meliaceae, Monimiaceae, Myrtaceae, Rubiaceae, Melianthaceae, Araliaceae, Leguminosae and Apocynaceae).

The Leguminosae is among the first families in FIV in the lowland and submontane forests (Table 14). It no longer has a representative in the highlander Manengouba forest and Kupe slopes above $1000 \mathrm{~m}$ (Noumi, 2013, Tchoua, 2014). The same scarcity is observed in an inventory of all plants $\geq 1 \mathrm{~cm} \mathrm{dbh}$ recorded in 19 sholas of total area 11.5 ha (Mohandass and Davidar, 2009). The Leguminosae are present in the study area with only one species: Piptadeniastrum africanum.

Gentry (1988) remark the dominance of Leguminosae in Neotropics and Africa is equal when only trees $\geq 10 \mathrm{~cm}$ $\mathrm{dbh}$ are considered. But in the high altitudes the Leguminosae decrease in abundance and even disappear in the highlander floor (Mohandass Davidar and, 2009; Noumi, 2013; Tchoua, 2014), whereas the Rubiaceae win in abundance with trees $\geq 10 \mathrm{~cm}$ dbh and invade the undergrowths with bushes $<10 \mathrm{~cm}$ dbh in Manengouba. Among the above mentioned families Araliaceae, Myrtaceae, Meliaceae, Rubiaceae, Monimiaceae, Leguminosae, Moraceae, Melianthaceae, Rutaceae, Euphorbiaceae, Apocynaceae and Maesaceae are among the 15 most important families for relative diversity and FIV in the plot sampled here (Table 14).

Leguminosae is less important in Oku sacred forest with ony 1 species but they are $6^{\text {th }}$ in FIV (FIV values: 18.54). On the other hand, in Oku sacred forest Araliaceae and Myrtaceae are the much more dominant and more abundant. At the present state of research in the description of the composition of the Cameroonian rainforests of altitude (submontane or transition forests and highlander forests), the above cited families, indicated like being the most representative, distribute themselves in 4 groups on the slopes and the humid and rainy reliefs, as followed (Noumi, 2015):
- goup of hygro - megathermal families (on the lowland floor) of which the relative density and the indications of the basal area decrease from $800 \mathrm{~m}$ of altitude : Leguminosae, Apocynaceae;

- Group of hygro - mesothermal families (on the submontane floor) of which the relative density and the indications of the area basal grow from $800 \mathrm{~m}$ of altitutde: Burseraceae, Clusiaceae, Meliaceae, Sapotaceae, Sterculiaceae;

- Group of hygro-oligothermal families (on the Afromontane floor) of which the relative density and the indications of the basal area grow regularly of low and middle altitudes to the altitudes highest or are confined to these altitudes: Araliaceae, Rubiaceae Monimiaceae Maesaceae, Melianthaceae, Myrtaceae and Rutaceae. They present high values in FIV in the Oku sacred forest (Table 8); But only Rubiaceae are the richest species (4 species);

- Group of the thermal indifferent families of which most species are hygromegathermal, some hygromesothermal and of other hygro-oligothermal: Euphorbiaceae, Moraceae ( $7^{\text {th }}$ in FIV) in Oku (Table 8).

Either 14 families who share this vital space: Araliaceae, Burseraceae, Clusiaceae, Euphorbiaceae, Leguminosae, Maesaceae, Meliaceae, Melianthaceae, Monimiaceae, Myrtaceae, Rubiaceae, Rutaceae, Sapotaceae and Sterculiaceae.

It is remarkable that in the Cameroonian highland forests, Rubiaceae seem to be more important than in neotropical and African lowland forests. At Manengouba it is the first in FIV accumulation values (FIV: 56.19), while it is $4^{\text {th }}$ with an FIV of 24.64 in the Oku sacred forest, 4th with an FIV of 21.23 at Manongarivo (D'Amico and Gautier, 2000), $6^{\text {th }}$ with an FIV value of 14.71 at Yasuni (Balslev et al., 1987), 10th with an FIV value of 8.3 at Alto Ivon (Boom, 1986), $14^{\text {th }}$ with an FIV value of 7.79 at Jenera Herrera (Spichiger et al., 1996).

The scarcity of Rubiaceae is observed as recorded in many lowland forests (Table 14). On the one hand in Cameroon, Rubiaceae are much more abundant and more species-rich in the highland forests (Tagne, 2007; Madiapevo, 2008; Noumi, 2012). On the other hand at Oku Meliaceae, Monimiaceae are the much more abundant, the Rubiaceae and Araliaceae are the most diversified. 
Table 14. Family Importance Value of the 15 most important plant families in Oku and other Cameroonian submontane forests (5), montane forests (2) and 5 lowland tropical forests reported by D'Amico and Gautier (2000)

\begin{tabular}{|c|c|c|c|c|c|c|c|}
\hline \multicolumn{2}{|c|}{$\begin{array}{l}\text { Messa forest Cameroon) } \\
\text { (Tagne, 2007) }\end{array}$} & \multicolumn{2}{|c|}{$\begin{array}{l}\text { Kala forest (Cameroon) } \\
\text { (Madiapevo, 2008) }\end{array}$} & \multicolumn{2}{|c|}{$\begin{array}{l}\text { Mbam minkom forest } \\
\text { (Cameroon) (Noumi, 2015) }\end{array}$} & \multicolumn{2}{|c|}{$\begin{array}{l}\text { SF Kouoghap (Cameroon) } \\
\text { (Noumi, 2012) }\end{array}$} \\
\hline Leguminosae & 47.60 & Leguminosae & 31.00 & Clusiaceae & 60.01 & Meliaceae & 33.38 \\
\hline Moraceae & 28.93 & Myristicaceae & 26.80 & Burseraceae & 23.48 & Moraceae & 31.81 \\
\hline Euphorbiaceae & 26.11 & Burseraceae & 21.77 & Leguminosae & 17.28 & Sapotaceae & 26.83 \\
\hline Meliaceae & 17.26 & Sterculiaceae & 21.41 & Annonaceae & 16.81 & Rubiaceae & 26.12 \\
\hline Ulmaceae & 12.26 & Meliaceae & 17.83 & Apocynaceae & 14.52 & Euphorbiaceae & 15.74 \\
\hline Caricaceae & 10.57 & Euphorbiaceae & 15.78 & Euphorbiaceae & 13.86 & Verbenaceae & 12.51 \\
\hline Rubiaceae & 10.12 & Apocynaceae & 13.76 & Olacaceae & 9.54 & Annonaceae & 11.23 \\
\hline Bombacaceae & 7.44 & Irvingiaceae & 8.18 & Rubiaceae & 7.73 & Burseraceae & 9.65 \\
\hline Cecropiaceae & 7.38 & Moraceae & 8.13 & Oleaceae & 7.33 & Sterculiaceae & 9.33 \\
\hline \multicolumn{2}{|c|}{$\begin{array}{l}\text { Oku sacred forest } \\
\text { (Cameroon), present study }\end{array}$} & \multicolumn{2}{|c|}{$\begin{array}{l}\text { Manengouba forest } \\
\text { (Cameroon), Noumi, } 2013\end{array}$} & \multicolumn{2}{|c|}{$\begin{array}{l}\text { Kupe submontane forest } \\
\text { (Cameroon) Tchoua, } 2014\end{array}$} & \multicolumn{2}{|c|}{$\begin{array}{l}\text { Manongarivo (Madagascar), } \\
\text { (D’Amigo and Gautier, 2000) }\end{array}$} \\
\hline Families & FIV & Families & FIV & Families & FIV & Families & FIV \\
\hline Araliaceae & 49,15 & Rubiaceae & 56.19 & Meliaceae & 41.22 & Clusiaceae & 40.78 \\
\hline Myrtaceae & 39,03 & Euphorbiaceae & 55.71 & Rubiaceae & 32.40 & Euphorbiaceae & 29.09 \\
\hline Meliaceae & 37,88 & Araliaceae & 51.03 & Euphorbiaceae & 30.94 & Myrtaceae & 27.17 \\
\hline Rubiaceae & 24,64 & Myrsinaceae & 49.52 & Malvaceae & 23.55 & Rubiaceae & 21.23 \\
\hline Monimiaceae & 19,48 & Meliaceae & 16.06 & Burseraceae & 21.25 & Myristicaceae & 19.04 \\
\hline Leguminosae & 18,54 & Moraceae & 8.33 & Clusiaceae & 20.13 & Lauraceae & 16.32 \\
\hline Moraceae & 17,39 & Rutaceae & 7.95 & Moraceae & 17.24 & Burseraceae & 13.77 \\
\hline Melianthaceae & 15,64 & Cyatheaceae & 7.40 & Olacaceae & 15.53 & Sapotaceae & 10.48 \\
\hline \multicolumn{2}{|c|}{$\begin{array}{l}\text { Yasuni (Ecuator) } \\
\text { (Balslev et al., 1987) }\end{array}$} & \multicolumn{2}{|c|}{$\begin{array}{l}\text { Yapo (Côte d'Ivoire ) } \\
\text { (Corthay, 1996) }\end{array}$} & \multicolumn{2}{|c|}{$\begin{array}{l}\text { Alto Parana (Paraguay) } \\
\text { (Spichiger et al., 1992) }\end{array}$} & \multicolumn{2}{|c|}{$\begin{array}{l}\text { Alto Ivon (Bolivia) (Boom, } \\
\text { 1986). (Submountain going } \\
\text { up in lower highlander) }\end{array}$} \\
\hline Famille & FIV & Famille & FIV & Famille & FIV & Famille & FIV \\
\hline Arecaceae & 55.66 & Sapotaceae & 34.15 & Meliaceae & 44.4 & Moraceae & 53.3 \\
\hline Moraceae & 36.48 & Leguminosae & 32.27 & Lauraceae & 42.4 & Myristicaceae & 41.1 \\
\hline Leguminasae & 23.73 & Burseraceae & 24.83 & Sapotaceae & 39.4 & Palmae & 35.7 \\
\hline Bombacaceae & 19.66 & Euphorbiaceae & 18.88 & Leguminosae & 31.9 & Leguminosae & 30.1 \\
\hline Myristicaceae & 19.59 & Meliaceae & 18.70 & Rutaceae & 25.4 & Melastomataceae & 20.1 \\
\hline Rubiaceae & 14.73 & Sterculiaceae & 18.57 & Moraceae & 20.4 & Cecropiaceae & 15.3 \\
\hline Meliaceae & 11.62 & Ebenaceae & 15.49 & Boraginaceae & 14.7 & Vochysiaceae & 13.9 \\
\hline Euphorbiaceae & 8.15 & Clusiaceae & 14.85 & Arecaceae & 11.1 & Annonaceae & 8.7 \\
\hline Cecropiaceae & 7.86 & Olcaceae & 13.51 & Annonaceae & 10.1 & Chrysobalanaceae & 8.3 \\
\hline Lecythidaceae & 7.54 & Chrysobalanaceae & 12.08 & Bignoniaceae & 8.2 & Rubiaceae & 8.3 \\
\hline Lauraceae & 7.37 & Flacourtiaceae & 11.91 & Solanaceae & 4.6 & Lauraceae & 7.2 \\
\hline Sterculiaceae & 6.72 & Combretaceae & 8.75 & Myrtaceae & 3.5 & Burseraceae & 6.8 \\
\hline Flacourtiaceae & 6.18 & Lecythidaceae & 6.64 & Sapindaceae & 3.2 & Euphorbiaceae & 5.7 \\
\hline Polygonaceae & 6.07 & Irvingiaceae & 6.37 & Flacourtiaceae & 2.7 & Flacourtiaceae & 5.2 \\
\hline Sapotaceae & 5.59 & Scytopetalaceae & 6.35 & Euphorbiaceae & 2.5 & Myrtaceae & 4.5 \\
\hline
\end{tabular}


Specific level - In the present study 31 species were encountered. The number of species per hectare seems to be fluctuating in African highlander forest (31-106) (Table 15), as in other tropical lowland forests in Madagascar: 38-146 (Rakotomalaza andMessmer, 1999; Rabevohitra et al., 1996) and in the Neotropical region: 94 at Alto Ivon (Bolivia) (Boom, 1986), but less than 228- in Amazonian Ecuador (Balslev et al., 1987). Lower diversity values were always recorded in the tropical montane forests like in Sao Tomé (P. N. Obo) where White (1983) found 40 species/ha, like in Cameroon (Manengouba) where Noumi (2013) found found 41 species/ha and in the present study where the authors found 30 species /ha. The proportion 70 species/ha found by Mohandass and Davidar (2009) in Nilgiri, India concern the woody with $\mathrm{dbh} \geq 1 \mathrm{~cm}$ and would be well least so only the woody with $\mathrm{dbh} \geq 10 \mathrm{~cm}$ had been taken in account.

Table 15. Number of species tallied $(\mathrm{dbh}>10 \mathrm{~cm})$ per ha in Mbam minkom, and African other, Malagasy and neotropic rainforests (altitudes available).

\begin{tabular}{lllll}
\hline Sites & $\begin{array}{l}\text { Middle } \\
\text { altitude (m) }\end{array}$ & Country & Reference & $\begin{array}{l}\text { Number of } \\
\text { species/ha }\end{array}$ \\
\hline $\begin{array}{l}\text { Low elevation rainforests sites } \\
\text { Scio Classified forest alt. moyenne }\end{array}$ & 230 & Côte d'Ivoire & $\begin{array}{l}\text { Nusbaumer et al. (2005) } \\
\text { Corthay (1996) }\end{array}$ & 89 \\
$\begin{array}{l}\text { Yapo classified forest } \\
\text { Dja Forestry Reserve (Alat 1.7) }\end{array}$ & 230 & $\begin{array}{l}\text { Côte-d'Ivoire } \\
\text { Cameroon }\end{array}$ & 57 \\
Submontane rainforests sites & $500-700$ & Sonké (1998) & 79 \\
P.N. Mt. Alen & $350-1200$ & Equatorial Guinea & Van Reeth (1997) & 106 \\
Manongarivo & $750-1.200$ & Madagascar & D'Amico and Gauttier (2000) & 90 \\
Messa & $900-1015$ & Cameroon & Tagne (2007) & 151 \\
Kala & $1000-1156$ & Cameroon & Madiapevo (2008) & 178 \\
Mbam minkom sub-moutane forest & $1000-1295$ & Cameroon & Noumi (2015) & 58 \\
Kouoghap sacred Forest & $1400-1550$ & Cameroon & Noumi (2012) & 31 \\
Kupe submontane forest, & $1000-1800$ & Cameroon & Thoua (2014) & 156 \\
Montane rainforests sites & & & & \\
P.N Obo & $0-2024$ & Sao Tomé & White (1983) & 40 \\
Shola montane evergreen forest & $2000-2633$ & Nilgiri, India & Mohandass and Davidar & 70 \\
Oku sacred forest & $2200-2300$ & Cameroon & (2009) & 30 \\
Manengouba forest (Mbouroukou) & $2200-2396$ & Cameroon & Noumi (2013) & 41 \\
\hline
\end{tabular}

In the lowland forests and according to Rollet (1983), $50 \%$ of individuals on average are represented by 20 species in disturbed lowland Amazonian forests of Venezuela. In Manonagrivo, half of the trees are represented by only 11 species. A similar value (12 species) was found at Andohahela, Madagascar (Rakotomalaza and Messmer, 1999). In the submontane forests the number of species that reach $50 \%$ of individuals decreases with the altitude: - 17 species (52.01\% of individuals) at Messa in Cameroon (Tagne, 2007); -15 species (52.53\% of individuals) at Kupe in Cameroon (Tchoua, 2014); - 6 species $(50 \%$ of individuals) at Kala in Cameroon (Madiapevo, 2008); - 5 species (54.07 of individuals) at Mbam minkom in Cameroon (Noumi, 2015).

In the undisturbed montane forest, more than $50 \%$ of individuals are only represented by some species: $53.64 \%$ of the trees at Oku (present study) by 3 species; $53.08 \%$ of trees at Manengouba in Cameroon by 4 species. One can evoke for the Afrotropical highlander forests, the character often gregarious of the dominant species, having for consequence the small number of species associated in the superior strata, and a certain floristic poverty of the specifically arborescent core. These plant species are among the ten first in FIV due to their relative density. In high altitude numerous plants are gregarious.

The Shannon diversity index $\left(H^{\prime}\right)$ (Shannon and Weaver, 1949) permits a good approach of the diversity on the different plots because it takes into account the number of species and the distribution of abundances. Its calculated values for different Guinean forests are between 4 and 6.5. The Oku sacred formation presents a low value $\left(H^{\prime}=3.71\right)$, which shows a less diversified forest, with gregarious species (Table 15). 
Table 16. Family Importance Value of the 10 most important plant species in Oku sacred forest and other Guinean forests

\begin{tabular}{|c|c|c|c|c|c|c|c|}
\hline \multicolumn{2}{|c|}{$\begin{array}{l}\text { Messa forest, Cameroon (Tagne, } \\
\text { 2007). Alt. } \\
\text { Cameroon, }\end{array}$} & \multicolumn{2}{|c|}{$\begin{array}{l}\text { Kala forest, Cameroon } \\
\text { (Madiapevo, 2008). Alt. } 1156 \text { m }\end{array}$} & \multicolumn{2}{|c|}{$\begin{array}{l}\text { Mbam Minkom forest, } \\
\text { Cameroon (Noumi, 2015). Alt. } \\
\text { 1000-1295 m }\end{array}$} & \multicolumn{2}{|c|}{$\begin{array}{l}\text { Koupe forest, Cameroon, } \\
\text { (Tchoua, 2014). Alt 1000-1800 } \\
\text { m }\end{array}$} \\
\hline Species & IVI & Species & IVI & Species & IVI & Species & IVI \\
\hline Cylicomorpha solmsii & 11.40 & $\begin{array}{l}\text { Allanblackia } \\
\text { gabonensis }\end{array}$ & 20.71 & Garcinia lucida & 38.52 & Santiria trimera & 19.64 \\
\hline Anthonotha fragrans & 11.13 & $\begin{array}{l}\text { Strombosia } \\
\text { grandifolia }\end{array}$ & 14.40 & Cola verticillata & 24.29 & Carapa procera & 19.31 \\
\hline $\begin{array}{l}\text { Trilepisium } \\
\text { madagascariensis }\end{array}$ & 11.05 & Santiria trimera & 9.93 & Santiria trimera & 21.04 & Cola acuminata & 15.56 \\
\hline Cola cordifolia & 10.76 & $\begin{array}{l}\text { Tarbernaemontana } \\
\text { crassa }\end{array}$ & 8.11 & $\begin{array}{l}\text { Allanblackia } \\
\text { gabonensis }\end{array}$ & 18.34 & $\begin{array}{l}\text { Penianthus } \\
\text { longifolius }\end{array}$ & 14.72 \\
\hline Pycnanthus angolensis & 9.26 & Oelocarion preussii & 7.19 & $\begin{array}{l}\text { Pycnanthus } \\
\text { angolensis }\end{array}$ & 9.39 & Dripetes leonensis & 13.01 \\
\hline $\begin{array}{l}\text { Ricinodendron } \\
\text { heudelotii }\end{array}$ & 7.92 & Cola verticillata & 6.45 & $\begin{array}{l}\text { Tabernaemontana } \\
\text { crassa }\end{array}$ & 8.01 & $\begin{array}{l}\text { Strombosia } \\
\text { pustulata }\end{array}$ & 12.30 \\
\hline $\begin{array}{l}\text { Triplochiton } \\
\text { scleroxylon }\end{array}$ & 7.29 & $\begin{array}{l}\text { Pycnanthus } \\
\text { angolensis }\end{array}$ & 6.44 & Linociera oreophila & 5.80 & $\begin{array}{l}\text { Turraeanthus } \\
\text { africanus }\end{array}$ & 11.58 \\
\hline $\begin{array}{l}\text { Tabernaemontana } \\
\text { crassa }\end{array}$ & 6.91 & $\begin{array}{l}\text { Aulacocalyx } \\
\text { jasmiflora }\end{array}$ & 6.28 & $\begin{array}{l}\text { Leplaea } \\
\text { mayombensis }\end{array}$ & 5.52 & $\begin{array}{l}\text { Pycnanthus } \\
\text { angolensis }\end{array}$ & 10.27 \\
\hline Sterculia tragacantha & 6.79 & Cola attiensis & 5.65 & Drypetes parviflora & 5.42 & $\begin{array}{l}\text { Englerophytum } \\
\text { stelechanthum }\end{array}$ & 9.87 \\
\hline Carapa procera & 6.70 & $\begin{array}{l}\text { Greenwayodendron } \\
\text { suaveolens }\end{array}$ & 5.62 & $\begin{array}{l}\text { Strombosia } \\
\text { grandifolia }\end{array}$ & 5.41 & $\begin{array}{l}\text { Allanblackia } \\
\text { gabonensis }\end{array}$ & 8.72 \\
\hline \multicolumn{2}{|c|}{$\begin{array}{l}\text { Kouoghap sacred forest, } \\
\text { Cameroon (Noumi, 2012). Alt. } \\
1400-1550 \mathrm{~m}\end{array}$} & \multicolumn{2}{|c|}{$\begin{array}{l}\text { Oku sacred forest, Cameroon } \\
\text { (present study). Alt. 2000-2200 } \\
\text { m }\end{array}$} & \multicolumn{2}{|c|}{$\begin{array}{l}\text { Manengouba forest, } \\
\text { Cameroon (Noumi, 2013). } \\
\text { Alt } 2200-2295 \mathrm{~m}\end{array}$} & \multicolumn{2}{|c|}{$\begin{array}{l}\text { Forêt classée de Scio (Côte } \\
\text { d'Ivoire), (Nusbaumer et al., } \\
\text { 2005). Alt. Moyenne: } 230 \text { m }\end{array}$} \\
\hline Species & IVI & Species & IVI & Species & IVI & Species & IVI \\
\hline $\begin{array}{l}\text { Syncepalum } \\
\text { cerasiferum }\end{array}$ & 28.24 & Schefflera mannii & 43.29 & $\begin{array}{l}\text { Macaranga } \\
\text { occidentalis }\end{array}$ & 37.35 & $\begin{array}{l}\text { Calpocalyx } \\
\text { brevibracteatus }\end{array}$ & 32.01 \\
\hline Tricalysia macrophylla & 24.04 & Carapa grandiflora & 40.54 & $\begin{array}{l}\text { Rapanea } \\
\text { melanophloeos }\end{array}$ & 30.48 & Polyalthia oliveri & 27.76 \\
\hline $\begin{array}{l}\text { Trilepisium } \\
\text { madagascariensis }\end{array}$ & 17.87 & Syzygium guineense & 35.95 & Maesa lanceolata & 26.08 & $\begin{array}{l}\text { Piptadeniastrum } \\
\text { africanum }\end{array}$ & 16.16 \\
\hline Markhamia tomentosa & 17.29 & Xymalos monospora & 22.14 & Polyscias fulva & 24.16 & $\begin{array}{l}\text { Petersianthus } \\
\text { macrocarpus }\end{array}$ & 15.98 \\
\hline Funtumia africana & 14.98 & $\begin{array}{l}\text { Piptadeniastrum } \\
\text { africanum }\end{array}$ & 20.55 & $\begin{array}{l}\text { psydrax } \\
\text { arnoldianum }\end{array}$ & 23.44 & Baphia pubescens & 14.16 \\
\hline Vitex grandifolia & 13.92 & Nuxia congesta & 17.39 & $\begin{array}{l}\text { Rothmannia } \\
\text { urcelliformis }\end{array}$ & 22.30 & Scottellia klaineana & 10.48 \\
\hline Lovoa trichilioides & 10.01 & Ficus thonningii & 13.02 & Schefflera barteri & 18.85 & $\begin{array}{l}\text { Erythrophleum } \\
\text { ivorense }\end{array}$ & 9.57 \\
\hline Polyscias fulva & 8.87 & Bersama abyssinica & 10.26 & Carapa grandiflora & 11.64 & $\begin{array}{l}\text { Corynanthe } \\
\text { pachyceras }\end{array}$ & 9.04 \\
\hline Dracaena arborea & 7.50 & $\begin{array}{l}\text { Rauvolfia } \\
\text { macrophylla }\end{array}$ & 9.77 & Schefflera mannii & 10.57 & Funtumia elastica & 8.92 \\
\hline Trichilia rubescens & 7.21 & Rytigynia neglecta & 8.31 & $\begin{array}{l}\text { Croton } \\
\text { macrostachyus }\end{array}$ & 9.81 & $\begin{array}{l}\text { Strombosia } \\
\text { pustulata }\end{array}$ & 8.52 \\
\hline
\end{tabular}

Mori et al. (1983) consider as rare species those who are found only once in the sample. In a lowland forest of eastern Brazil $41 \%$ species were rare according to this definition. The percentages of species represented by only one individual were $55 \%$ in unflooded forest and $62 \%$ in a floodplain forest of Ecuador (Balslev et al., 1987). A forest inventory in Andohahela, Madagascar (Rakotomalaza and Messmer, 1999) recorded a value of $38.8 \%$.
In the highland forests, the percentages of rare species are: - 20.54\%- (Noumi, 2015) in Mbam minkom; - $28 \%$ - (Tagne, 2007) in Messa; - 32.5\% - (Noumi, 2013) in Manengouba. In this study the percentage of species represented by only one individual $(9.67 \%)$ is much lower than these reported in all the above mentioned studies and is close to the value reported in Kala - 12,5\% - (Madiapevo, 2008). The ratio of individual/species in the 1.125-ha plot of Oku sacred forest is 30.12. It is 
higher than the one of Menengouba montane forest, 18.65. In other 1-ha plots in Madagascar, recorded values were 6.1 (Rakotomalaza and Messmer, 1999) and 9.17 to 22.1 (Rabevohitra et al., 1996). In Cameroon the individual/species ratios found in the submontane forest are -8.03- Tagne (2007) and -10.05 -Madiapevo (2008). A series of 1-hectare forest inventories sampled in the neotropics recorded the following values: 8.42 in Southern Bahia, Brazil (Mori et al., 1983); 2.05 in Jenaro Herrera (Spichiger et al., 1996). The high individual/species ratio shows a less diversified forest, with gregarious tendency of species.

The IVI of Schefflera mannii, the species with the highest value in the plot, is 43.29. Similar values were recorded in a gallery forest of Mogi-Guaçu, Brazil (Spichiger et al., 1996) where the highest IVIs were 37.7 and 43.5; in Manengouba - 37.35 - (Noumi, 2013); in Mbam minkom - 38.49 - (Noumi, 2015) and these values fall to 28,24 (Noumi, 2012); to the 12.5-28.7 range of highest IVI recorded by Mori \& Boom(1987) in the lowland moist forests (Baslev et al., 1987); to 20.71- (Madiapevo, 2008) at Kala forest and to -16.37(Tagne, 2007) at Messa forest.

One would say that strongest IVI values don't depend to the mesologic characters, evolve with the altitudinal gradient pressure, therefore inversely proportional to the thermal pressure gradient. It is necessary to notice that in all inventories of the Table 16 a species with an IVI value higher than 10 always belongs to one of the ten highest IVIs of the sample.

The structure and diversity of the Oku sacred montane forest were a bit similar to that of the Manengouba montane forest. About $9(29.03 \%)$ of the species were common, indicating a common heritage of the two forests which are about $160 \mathrm{~km}$ apart in the SouthNorthern axis. They are Allophylus bullatus, Bersama abyssinica, Carapa randiflora, Croton macrostachyus, Maesa lanceolata, Polyscias fulva, Psydrax arnoldiana, Rapanea melanophloeo, Schefflera abyssinica and Schefflera mannii. Both Oku and Manengouba supported low-diversity forests with high basal area contributed by large trees specialy at Oku (Noumi, 2013).

\section{Phytogeographical affinities}

The phytogeographic affinities of the species recorded falls within ten major distributions (Fig. 13); 54.87\% species are widespread in the Guineo-congolese element. The extensively widespread species $(45.17 \%)$ are either endemic of the Cameroonian highlander archipelago, including Biko (ex Fernando Po), either distributed in the tropical region with the montanes of Oriental Africa and southern Africa, and their populations are thus geographically discontinuous.

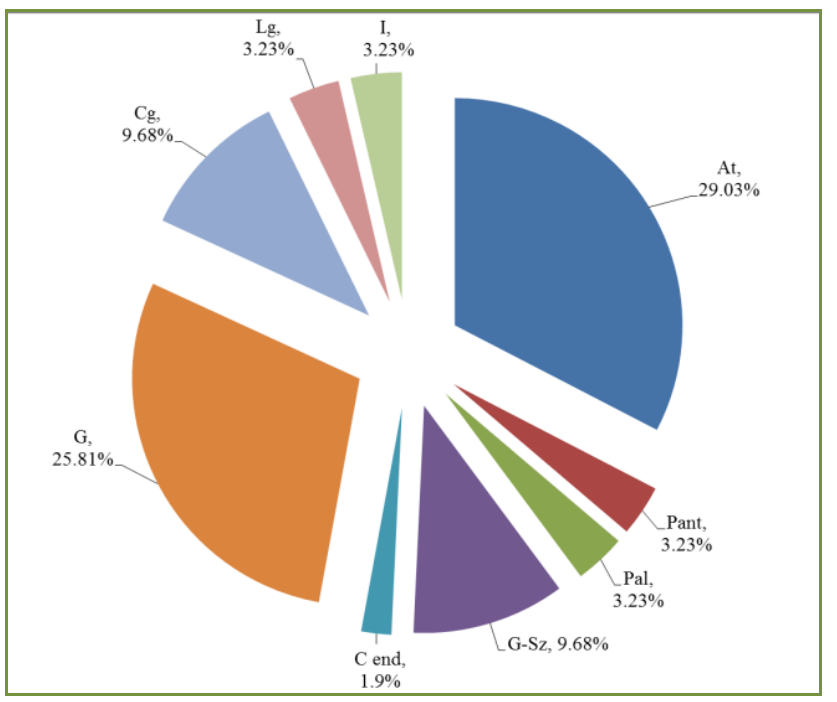

Fig. 13: Distribution of the identified speciesif the Oku 1.125ha plot according to main geographic patterns. Wide distribution species; At: Tropical Africa, Pant: Pantropical; Pal: Paleotropical; G-Sz: Guineo-Sudano-Zambezian. Guineo-congolian species; End C: endemic to Cameroonian high montane achipelago; G: Omni or sub omni GuineoCongolian; Centro-guineo-congolian; Lg: Lower Guinian; I: indeterminate.

\section{Phytosociological affinities}

The site of the Oku sacred forest is in a depression safe from the monsoon (humid wind) coming from the Atlantic Ocean. The continentality and the phenomenon of side opposition orient the hygrometric pressure gradient downwards. The 31 species are shared with rainforests, secondary and mesophiles forests (Fig. 14). This last is represented by Piptadeniastrum africanum, tolerant heliophyte plant species, scattered by win, deciduous leaves, whose individuals reach some diameters superior to $198 \mathrm{~cm}$, an abundance of 42 individuals and a basal area of $30.05 \mathrm{~m}^{2}$. However the luminous fraction to the level of soil is revealed at the time of the period of strong defoliation of the sylve (December - February) (Fig. 3), also due to the clear undergrowth as upper-indicated (in the Study erea).The species is one of features of the semi - caducifolious forests mesophiles of low and middle altitudes; order of the Piptadenio-celtidetalia Lebrun and Gilbert 1954 (of Piptadeniastrum africanum and Celtis div. sp.). However, the presence of Piptadeniastrum africanum to 
$2200-2300 \mathrm{~m}$ of altitude, under a rainfall of more than $2305.1 \mathrm{~mm}$ per year, appears to be independent of the climatic considerations. There is in the Oku sacred forest the discrepancies of sociological belongings that raises a lot more to paleogeomorphological phenomena and that make of this plant formation a sygenetic forest (with the formed together plant species, whose birth is common).

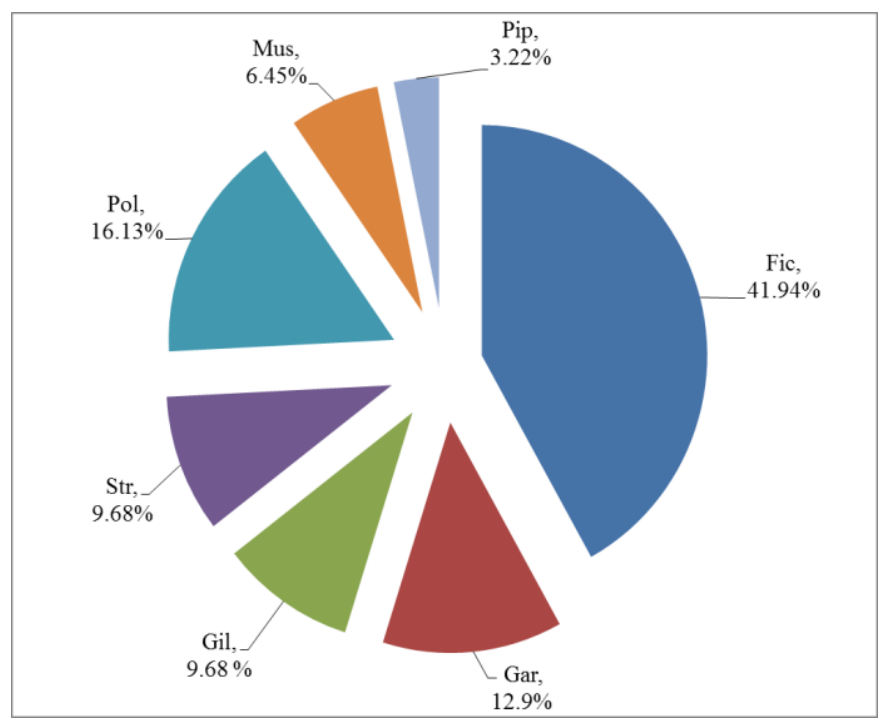

Fig. 14: Distribution of the identified species of the Oku 1.125-ha plot according to main ecosociological patterns. Rainforests; Fic: Ficalhoeto-Podocarpetalia, Gar: Garcinietalia, Gil: Gilbertiodendretalia dewevrei, Str: Strombosio-Parinarietea. Secondary forests; Pol: Polyscietalia fulvae, Mus: Musango-Terminalietea. Mesophile forest; Pip: Piptadenio-celtidetalia.

\section{Conclusion}

The comparison between the data of the Oku sacred forest and those of the Manengouba highlander forest and 4 submontanes forests (Kouoghap, Mbam minkom, Kala and Messa), bring closer the studied forest to the type Afro-highlander, hygro-oligothermal, if one only considers the trees of $\mathrm{dbh} \geq 10 \mathrm{~cm}$, by the Family Importance Values (FIV) and the Index of Importance Value of the species (IVI). About the point of view of the structure, the formation shows big diameter trees constructed by the stranglers' epiphytes from top to bottom. These elements make of the Oku sacred sylve a forest, singular by atypical trees stems descended of the stranglers' epiphytes. If one considers all ecosociological types, the comparisons bring more the forest studied closer to those of transition (hygro-mesothermal) and to those of low and middle altitudes (hygro-megathermal) with as characteristic Piptadeniastrum africanum. This remark is valid for the qualitative and quantitative data as the specific diversity of the families or the presence of the exclusive species of these three types of forest.

The philosophy developed from this shows that the Oku sacred forest is not the expression of the climate. It represents a plant formation particular enough containing therefore the species of the 3 different forest ecologies. These fundamental arguments make of the Oku sacred forest a syngenetic formation. They show the interest of the conservation of the Oku sacred forest that is structurally intact to the level of the strata, that of the flora. The back-up strategy of the forester heritage setting up by the villager collectivity must be encouraged.

\section{Conflict of interest statement}

Authors declare that they have no conflict of interest.

\section{Acknowledgement}

We transmit our acknowledgments to "International Tropical Timber Organisation" (ITTO) for the financial support of our fieldworks through the "Centre pour l'Environnement et le Développement" (CED) and the organisation 'Environnement-RechercheDéveloppement" (ERD) for the material support. Our thanks also go to the local populations for their multiform cooperations.

\section{References}

Asanga, C., 2002. Case study of exemplary forest management in Central Africa: community forest management at the kilum-Ijim mountain forest region, Cameroon. Forest Management.Working Papers, FM/11, Forest Resources Development Service, Forest Resources Division, FAO, Rome. 43p.

Aubréville, A., Leroy, J.F., Flore, G., 1963-1998. Flora of Cameroon, Vol. 1 to 34. National Museum of Natural History, Laboratory of the Phanerogames, Paris.

Bagnouls, F., Gaussen, G., 1957. Climats biologiques et leur classification. Ann. Géo. 355, 193-220.

Balslev, H.J., Luteyn, B., Ollgaard, L.B., Holm-Nielsen, 1987. Composition and structure of adjacent unflooded and floodplain forest in Amazonian Ecuator.Opera Bot. 92, 37-57.

Bibby, C.J., Collar, N.J., Crosby, M.J., Heath, M.F., Imboden, C., Johnson, T.H., Long, A.J., Stattersfield, A.J., Thirgood, S.J., 1992. Putting Biodiversity on the Map: Priority Areas for Global Conservation. International Council for Bird Preservation, Cambridge. pp.1-87.

Boom, B.M., 1986. A Forest inventory in Amazonian Boliva. Biotrop 18, 287-294. 
Cable, S., Cheek, M., 1998. The Plants of Mount Cameroon. A Conservation Checklist. Royal Botanic Gardens, Kew. $198 \mathrm{p}$.

Cheek, M., Onana, J.M., Pollard, B.J., 2000. The Plants of Mount $\mathrm{Oku}$ and the Ijim Ridge, Cameroon, A Conservation Checklist. Royal Botanic Garden, Kew. $211 \mathrm{p}$.

Collin, C., 1998. Study of the Biodiversity of the Woody Plants of the Ndote Forest (Equatorial Guinea). End of study work, Free University of Brussels. Lab. Syst. Bot. Phytosociol. 79p.

Corthay, R., 1996. Floristic Analysis of the Yapo Rainforest (Côte d'Ivoire). Diploma thesis, University of Geneva.

Cottam, G., Curtis, J.T., 1956. The use of distance measures in phytosociological sampling. Ecol. 37, 451-460.

Curtis, J.T., McIntosh, R.P., 1951. The interrelations of certain analytic and synthetic phytosociological characters. Ecol. 31, 434-455.

D’Amico, C., Gautier, L., 2000. Inventory of a 1-ha lowland rainforest plot in Manongarivo (NW Madagascar). Candollea. 55, 319-340.

Gentry, A.H., 1982. Patterns of Neotropical plant species diversity. Evol. Biol. 15, 1-84.

Gesnot, K., 1994. Forest Inventory in the Bees Forest (Gabon). End of Study Work, Free University of Brussels. 108p.

Hawkins, P., Brunt, M., 1965. The Soil and Ecology of West Cameroon. FAO, Rome. 661p.

Hutchinson, J., Dalziel, J.M., 1954-1972. Flora of West Tropical Africa. Vol 1-3. Milbank, London, England.

Julve, Ph., 1998. ff. - Baseflor. Index botanique, écologique et chorologique de la flore de France. Version 23 avril 2004.

Lebrun, J.P.S., Stork, A.L., 1191, 1992, 1995 and 1997. Induction of the flowering plants of tropical Africa, 4 Volumes. Editions of the Conservatories and Garden Botanies of the City of Geneva, Switzerland.

Lebrun, J., Gilbert, 1954. An ecological classification of the Belgian Congo forests. Publ. INEAC, Series Sci. 63, 101.

Lejoly, J., 1995. Use of the transect method in the survey of biodiversity in the conservation zone of the Ngotto forest Centrafrican Republic. Technic report. Ecofac, AgrecoCTFT Project. 114p.

Letouzey, R., 1985. Note of the phytogeograhic map of Cameroon at 1/500000. IRA, Yaoundé. 240p.

Madiapevo, S.N., 2008. Study of the diversity and the structure of the woody plant of the submountain forest of the Kala mount $(1156 \mathrm{~m})$, region of Yaoundé. Memory of DEA, University of Yaoundé I. 71p.

Mailleux, A.C., Molenberg, J.M., Grégoire, J.C., 2007. Megastigmus spermotrophus, ravageur de graines de douglas, et ses ennemis naturels en Wallonie. Forêt Wallonne 87, 49-56.

McLeod, H.L., 1987. The conservation of Oku Mountain Forest, Cameroon. Study Report N¹5. 90p.

Mohandass, D., Davidar, P., 2009. Floristic structure and diversity of a tropical montane evergreen forest (shola) of the Nilgiri Mountains, Southern India. Trop. Ecol. 50(2), 219-229.
Momo, S.M.C., 2009. Influence des activités anthropiques sur la végétation du Mont Oku (Cameroun). Thèse en Biologie-Santé, Univ de Picardie et Univ de Youndé I. 262p.

Mori, S.A., Boom, B.M., 1987. The Lecytidaceae of a lowland Neotropical forest, La Fumée mountain, French Guinea, chapter II. The forest Mem. New York Bot. Garden 44, 929.

Mori, S.A., Boom. B.M., Carvalho, A.M., Dos Santos, T.S., 1983. Ecological importance of Myrtaceae in an Eastern Brazilian wet forest. Biotrop. 15, 68-70.

Normand, M.D., 1965. Identification of the trees and the woods of the main forest species in the Centrafrican Republic. CTFT, Nogent-sur-Marne. 78p.

Noumi, E., 1998. The "Transition Forest" of Garcinia spp. of the Nkolobot hills (Region of Yaoundé, Cameroon). Belg. J. Bot. 130(2), 198-220.

Noumi, E., 2008. Didactique des sciences de la vie et de la terre (SVT) illustrée par des exemples et docimologie : Manuel des professeurs des lycées et collèges. Yaoundé: Edition GIC- ICSSC.(Reprographie). 55p.

Noumi, E., 2012. Ligneous flora diversity of a submountain forest of west Cameroon; the Kouoghap sacred forest of the village Batoufam. J. Ecol. Nat. Env. 4(1), 8-28.

Noumi, E., 2013. Floristic inventory of woody species in the Manengouba Mountain forest, Cameroon. J. Biol. Life Sci. 4(2), 282-309.

Noumi, E., 2015. Floristic structure and diversity of a tropical sub-montane evergreen forest, in the Mbam minkom massif (Western Yaoundé). J. Biol. Life Sci. 6(1), 149193.

Nusbaumer, L., Gautier, L., Chatelin, C., Spichiger, R., 2005. Floristic structure and composition of the classified forest of the Scio (Côte d'Ivoire). Descriptive and comparative study. Candollea. 60(2), 393-443.

Piélou, E.C., 1966. Species diversity and Pattern diversity in study of ecological succession. J. Theor. Biol. 10, 370383.

Rabevohitra, R., Lowry II, P.P., Randrianjafy, H., Schatz, G.E., Razafindrianilana, N., 1996. Assessment of Plant Diversity and Conservation Importance of East Coast low Elevation Malagasy Rainforests. Report on the Project: National Center of Research Applied to the Farming Development, Madagascar. Department of Forest and Piscicoles Research, Madagascar. Biodiversity Support Program. Missouri Botanic Garden. St Louis.

Rakotomalaza, P.I., Messmer, N., 1999. Structural and floristic composition of the vegetation in the Reserve natural integral of Andohahela, Madagascar. In: A Floral and Faunal Inventory of the Reserve Natural Integral of Andohahela, Madagascar: with Reference to Elevational Variation (Ed.: Goodman, S.M.). Fieldiana Zoology, New Series 94. pp.51-96.

Reitsma, J.M., 1988. Forest vegetation of Gabon. The Tropenbos Foundation, Ede, Netherlands. 142p.

Robert, V. P., 2001. Forest Giants of the Pacific Coast, University of Washington Press. 
Rollet, B., 1983. The natural regeneration in the openings. A general process of the dynamics of the humid tropical forests. Woods and Forests of the Tropics 201: 3-34.

Rollet, B., 1979. Application of various methods of analyses of data to detailed forest inventories raised in tropical forest. Oecol. Plant 14(3), 319-344.

Senterre, B., Lejoly, J., Sonké, B., 2004. Analysis of the pressure gradient of continentality and identification of plant communities in rainforests of central Africa by the method of the mega transect. Phytocoenol. 34(3), 491-516.

Senterre, B., 2005. Methodological Research for the Typology of the Vegetation and the Phytogeography of the Tropical Africa Rainforests. Doctorate thesis in Agro Sci. Biol. Engineering. Free University of Brussels. 347p.

Shannon, C.E., Weaver, W., 1949. The mathematical theory of communication. Urbana Univ. Press, Illinois. pp.117-127.

Sokpon, N.S., 1995. Ecological Research on the Moist Semideciduous Forest of the Cleistopholis patens and Ficus тисиso Forest in the South-East of Benin: Plant Groupings, Natural Regeneration and Fall of the Litter. Thesis of Doctorate, Free University of Brussels, Belgium. $350 \mathrm{p}$.

Sonke, B., 1998. Floristic and Structural Studies of the Dja Reserve of Fauna Forests (Cameroon). Doctorate thesis, Free University of Brussels. 267p.

Spichiger, R., Loizeau, P.A., Latour, C., Barriera, G., 1996. Tree species richness of South-Western Amazonian forest (Jenero Herrera, Peru, $73^{\circ} 40^{\prime} \mathrm{W} / 4^{\circ} 54^{\prime} \mathrm{S}$ ). Candollea. 51, 559-577.

Spichiger, R., Bertoni, B.S., Loizeau, P.A., 1992. The forest of Alto Parana. Candollea. 47, 219-250.

Stattersfield, A.J., Crosby, M.J., Long, A.J., Wege, D.C., 1998. Endemic Bird Areas of the World -Priorities for Biodiversity Conservation. BirdLife Conservation Series $\mathrm{n}^{\circ}$ 7, Cambridge, UK.

Tagne, T.G.A., 2007. Floristic and Structural Study of the Ligneous Flora of the Submountain Forest of the Messa Hill (Yaoundé). Memory of DEA thesis, University of Yaoundé I. 66p.
Tchoua, T.J.M., 2013. Etude phytogéographique de l'étage submontagnard du Mont Koupé (Moungo-Cameroun). Mém. de Master. Université de Yaoundé I. 50p.

Thomas, D., Gardner, A., De Marco, J., 2001. Devolution of decision-making: Lessons from community forest management at the Kilum-Ijim forest project, Cameroon. In: Conflict and Co-operation in Participatory Natural Resource Management (Eds.: Jeffrey, R., Vira, B.). Global Issue Series. pp.189-203.

Van Asbroeck, P., 1997. Survey of the Plant Biodiversity of the Woody in the Forest of the National Park of Odzola (Republic of Congo). End of Study Work. Lab. Syst. Bot. Phytosociol., Free University of Brussels, Brussels, Belgium. 107p.

Van Reeth, L., 1997. Analysis of the Biodiversity of the Ligneous Flora in the National Park of Monte Alén in Équatorial Guinea. End of Study Work. Lab. Syst. Bot. Phytosociol., Free University of Brussels, Brussels, Belgium. 119p.

Villanueva, A.G., 1991. Quantitative and Structural Assessment of a Humid Tropical Forest in View of its Forest in Iquitos-Peru. Thesis of Doctorate, Catholic University of Louvain, Louvain, Belgium. 181p.

Vivien, J., Faure, J.J., 1985. Trees in Dense Forests of Central Africa. ACCT, Paris. 565p.

Walter, H., Lieth, H., 1964. Klimadiagram - Weltatlas. G Fischer, Jena.

White, F., 1983. The Vegetation of Africa. A descriptive Memory to Accompany the UNESCO/AETFAT/UNSO Vegetation Map of Africa. Natural Resources Research 20, UNESCO, Paris. 356p.

White, J.T.L., 1992. Vegetation History and Logging Disturbance: Effects on Rainforest Mammals in the Lopé Reserve, Gabon (with Special Emphasis on Elephants and Apes). Ph.D. thesis, University of Edinburg, Edingburg. 250p.

Wild, C., 1994. The status and ecology of the montane herpetology of Mount Oku, Cameroon, Africa. ASRA J. 1994, 73-91.

\section{How to cite this article:}

Noumi, E., Tagne Tiam, G.A., 2016. Floristic inventory of woody species of the Oku sacred forest in the North-West Cameroon, theoretical and philosophical approach. Int. J. Curr. Res. Biosci. Plant Biol. 3(1), 66-91. doi: http://dx.doi.org/10.20546/ijcrbp.2016.301.009

\section{$\underline{\text { List of Appendices }}$}

Appendix 1: Floristic list of the Oku sacred forest, with some synthetic characteritics [individuals with diameter $(\mathrm{dbh}) \geq 10 \mathrm{~cm}]$.

Appendix 2. Diversity, density, basal area and FVI of the plant families encountered in the 1.125-ha sampling, in the Oku montane sacred Forest, presented by decreasing FIV.

Appendix 3. Ocurrency, density, basal area and IVI of the plant species encountered in the 1.125-ha sampling in the Oku mountane sacred forest, presented by decreasing IVI. 
Appendix 1. Floristic list of the Oku sacred forest, with some synthetic characteritics [individuals with diameter (db h) $\geq 10 \mathrm{~cm}]$.

\begin{tabular}{|c|c|c|c|c|}
\hline Families & Species & $\begin{array}{l}\text { Phytogeo- } \\
\text { graphical } \\
\text { types }\end{array}$ & $\begin{array}{l}\text { Altitudinal } \\
\text { variations }\end{array}$ & $\begin{array}{l}\text { Ecosociological } \\
\text { groups }\end{array}$ \\
\hline Rubiaceae & Aidia micrantha (K. Schum.) F. White & G & $\mathrm{Bm}$ & gil \\
\hline Sapindaceae & Allophylus bullatus Radlk. & End-Cam & $\mathrm{Mi}$ & Fic \\
\hline Myrsinaceae & Ardisia staudtii Gilg. & $\mathrm{Cg}$ & $\mathrm{Sm} / \mathrm{Mi}$ & gar \\
\hline Melianthaceae & Bersama abyssinica Fresen. & At & $\mathrm{Mi}$ & fic \\
\hline Melianthaceae & Bersama englerana Gürke & G-sz & $\mathrm{Sm}$ & gar \\
\hline Meliaceae & Carapa grandiflora Sprague & $\mathrm{G}$ & Mi & Fic \\
\hline Rutaceae & Clausena anisata (Willd.) Hook. f. ex Benth. & At & $\mathrm{Mi}$ & fic \\
\hline Euphorbiaceae & Croton macrostachyus Hochst. ex Del. & G & $\mathrm{Sm}$ & pol \\
\hline Myrtaceae & Eugenia gilgii Engl. \& V. Brehm. & $\begin{array}{l}\mathrm{G} \\
(\mathrm{Bg}) \text { Basse }\end{array}$ & $(\mathrm{Bm} / \mathrm{Sm})$ & gil \\
\hline Moraceae & Ficus chlamydocarpa Milbr. \& Burret & guinée & $\mathrm{Mi}$ & fic \\
\hline Moraceae & Ficus thonningii Blume & At + sub-at & $\mathrm{Sm} / \mathrm{Mi}$ & str \\
\hline Rubiaceae & Ixora breviflora Hiern. & $\mathrm{Cg}$ & $\mathrm{Sm}$ & gar \\
\hline Maesaceae & Maesa lanceolata Forssk & At + sub-at & $\mathrm{Sm} / \mathrm{Mi}$ & pol \\
\hline Maesaceae & Maesa sp. & & $\mathrm{Sm} / \mathrm{Mi}$ & pol \\
\hline $\begin{array}{l}\text { Convolvulaceae } \\
\text { Buddlejaceae }\end{array}$ & Neuropeltis acuminata (P. Beauv.) Benth.). & G & $(\mathrm{Bm} / \mathrm{Sm})$ & str \\
\hline (Loganiaceae) & Nuxia congesta $\mathrm{R}$. Br. Ex Fresen & At & $\mathrm{Mi} / \mathrm{Ms}$ & fic \\
\hline Leguminosae & Piptadeniastrum africanum (Hook. f.) Brenan & $\mathrm{G}$ & $\mathrm{Bm}$ & Pip \\
\hline Pittosporaceae & Pittosporum mannii Hook. f. & At & $\mathrm{Mi}$ & pol \\
\hline Araliaceae & $\begin{array}{l}\text { Polyscias fulva (Hiern) Harms } \\
\text { Psydrax arnoldiana (De Wild. \& Th. Dur.) }\end{array}$ & At & $\mathrm{Mi}$ & pol \\
\hline Rubiaceae & Hepper & $\mathrm{G}$ & $\mathrm{Sm}$ & gar \\
\hline Myrsinaceae & Rapanea melanophloeos (L.) Mez & G-sz & $\mathrm{Mi} / \mathrm{Ms}$ & fic \\
\hline Apocynaceae & Rauvolfia macrophylla Stapf & $\mathrm{Cg}$ & $\mathrm{Bm}$ & mus \\
\hline Rubiaceae & $\begin{array}{l}\text { Rytigynia neglecta (Hiern) Robyns } \\
\text { Schefflera abyssinica (Hochst. ex A. Rich.) }\end{array}$ & At & $\mathrm{Mi}$ & fic \\
\hline Araliaceae & Harms & At & Mi & fic \\
\hline Araliaceae & Schefflera mannii (Hook. f.) Harms & End-Cam & $\mathrm{Mi}$ & fic \\
\hline Euphorbiaceae & Shirakiopsis elliptica (Hochst.) Esser. & Pant & $\mathrm{Sm} / \mathrm{Mi}$ & str \\
\hline Asteraceae & Solanecio mannii (Hook. f.) C. Jeffrey & End-Cam & Mi & fic \\
\hline Myrtaceae & Syzygium guineense (Willd.) DC. & End-Cam & Mi & fic \\
\hline Ulmaceae & Trema orientalis (L.) Bl. & Pal & $\mathrm{Bm}$ & mus \\
\hline Monimiaceae & $\begin{array}{l}\text { Xymalos monospora (Harv.) Baill. ex Warb. } \\
\text { Zanthoxylum heitzii (Aubr. \& Pellegr.)P.G. }\end{array}$ & G-sz & $\mathrm{Mi}$ & fic \\
\hline Rutaceae & Waterman & $\mathrm{G}$ & $(\mathrm{Bm} / \mathrm{Sm})$ & Pip \\
\hline
\end{tabular}


Appendix 2. Diversity, density, basal area and FVI of the plant families encountered in the 1.125-ha sampling, in the Oku montane sacred Forest, presented by decreasing FIV.

\begin{tabular}{|c|c|c|c|c|c|c|c|}
\hline Family & $\begin{array}{l}\text { Number of } \\
\text { species }\end{array}$ & $\begin{array}{l}\text { Relative } \\
\text { diversity (\%) }\end{array}$ & $\begin{array}{l}\text { Number of } \\
\text { trees }\end{array}$ & $\begin{array}{l}\text { Relative } \\
\text { density }(\%)\end{array}$ & $\begin{array}{l}\text { Basal } \\
\text { area }\end{array}$ & $\begin{array}{l}\text { Relative } \\
\text { dominance (\%) }\end{array}$ & FIV \\
\hline Myrtaceae & 2 & 6.45 & 101 & 10.81 & 60.45 & 21.77 & 39.03 \\
\hline Rubiaceae & 4 & 12.90 & 96 & 10.28 & 4.04 & 1.45 & 24.64 \\
\hline Monimiaceae & 1 & 3.23 & 136 & 14.56 & 4.71 & 1.70 & 19.48 \\
\hline Leguminosae & 1 & 3.23 & 42 & 4.50 & 30.05 & 10.82 & 18.54 \\
\hline Moraceae & 2 & 6.45 & 12 & 1.28 & 26.81 & 9.65 & 17.39 \\
\hline Buddlejaceae & 1 & 3.23 & 28 & 3.00 & 25.45 & 9.17 & 15.39 \\
\hline Rutaceae & 2 & 6.45 & 8 & 0.86 & 3.42 & 1.23 & 8.54 \\
\hline Euphorbiaceae & 2 & 6.45 & 14 & 1.50 & 0.51 & 0.19 & 8.14 \\
\hline Apocynaceae & 1 & 3.23 & 40 & 4.28 & 0.71 & 0.25 & 7.76 \\
\hline Maesaceae & 2 & 6.45 & 7 & 0.75 & 0.12 & 0.04 & 7.25 \\
\hline Myrsinaceae & 2 & 6.45 & 5 & 0.54 & 0.15 & 0.05 & 7.04 \\
\hline Sapindaceae & 1 & 3.23 & 17 & 1.82 & 4.05 & 1.46 & 6.51 \\
\hline Total & 31 & 100 & 934 & 100 & 277.73 & 100 & 300 \\
\hline
\end{tabular}

Appendix 3. Ocurrency, density, basal area and IVI of the plant species encountered in the 1.125-ha sampling in the Oku mountane sacred forest, presented by decreasing IVI.

\begin{tabular}{|c|c|c|c|c|c|c|c|}
\hline Species & Occurrence & $\begin{array}{l}\text { Relative } \\
\text { occurrence } \\
{\left[\begin{array}{ll}\mathbf{x} & \mathbf{1 0 0} \%\end{array}\right]}\end{array}$ & $\begin{array}{l}\text { Number of } \\
\text { trees }\end{array}$ & $\begin{array}{l}\text { Relative } \\
\text { density } \\
{\left[\begin{array}{ll}\text { x } & 100 \%\end{array}\right]}\end{array}$ & Basal area & $\begin{array}{l}\text { Relative } \\
\text { dominance } \\
{\left[\begin{array}{ll}\text { x } 100 \%] \\
\end{array}\right.}\end{array}$ & $\begin{array}{l}\text { IVI } \\
\text { [x 300\%] }\end{array}$ \\
\hline Syzygium guineense & 10 & 6.53 & 82 & 8.78 & 62.71 & 22.58 & 37.9 \\
\hline Shirakiopsiselliptica & 1 & 0.65 & 2 & 0.21 & 0.04 & 0.01 & 0.88 \\
\hline Rauvolfia macrophylla & 8 & 5.23 & 40 & 4.28 & 0.71 & 0.25 & 9.77 \\
\hline Ficus chlamydocarpa & 1 & 0.65 & 1 & 0.11 & 2.99 & 1.08 & 1.84 \\
\hline Eugenia gilgii & 5 & 3.27 & 20 & 2.14 & 1.04 & 0.38 & 5.79 \\
\hline Piptadeniastrum africanum & 8 & 5.23 & 42 & 4.50 & 30.05 & 10.82 & 20.55 \\
\hline Psydra xarnoldiana & 7 & 4.58 & 27 & 2.89 & 0.54 & 0.19 & 7.66 \\
\hline Schefflera mannii & 9 & 5.88 & 41 & 4.39 & 91.69 & 33.01 & 43.29 \\
\hline Polyscias fulva & 2 & 1.31 & 3 & 0.32 & 0.21 & 0.08 & 1.70 \\
\hline Ardisia staudtii & 2 & 1.31 & 3 & 0.32 & 0.08 & 0.03 & 1.66 \\
\hline Pittosporum viridiflorum & 3 & 1.96 & 5 & 0.54 & 0.23 & 0.08 & 2.58 \\
\hline Nuxia congesta & 8 & 5.23 & 28 & 3.00 & 25.45 & 9.17 & 17.39 \\
\hline Xymalos monospora & 9 & 5.88 & 136 & 14.56 & 4.71 & 1.70 & 22.14 \\
\hline Bersama abyssinica & 8 & 5.23 & 40 & 4.28 & 2.07 & 0.75 & 10.26 \\
\hline Solanecio mannii & 3 & 1.96 & 12 & 1.28 & 0.24 & 0.09 & 3.33 \\
\hline Schefflera abyssinica & 1 & 0.65 & 1 & 0.11 & 4.34 & 1.56 & 2.32 \\
\hline Maesa sp. & 3 & 1.96 & 3 & 0.32 & 0.05 & 0.02 & 2.30 \\
\hline Allophylus bullatus & 6 & 3.92 & 17 & 1.82 & 4.05 & 1.46 & 7.20 \\
\hline Neuropeltis acuminata & 6 & 3.92 & 20 & 2.14 & 0.35 & 0.13 & 6.19 \\
\hline Bersama engleriana & 6 & 3.92 & 18 & 1.93 & 6.19 & 2.23 & 8.08 \\
\hline Ixora breviflora & 4 & 2.61 & 16 & 1.71 & 2.15 & 0.77 & 5.10 \\
\hline Ficus thonningii & 5 & 3.27 & 11 & 1.18 & 23.82 & 8.58 & 13.02 \\
\hline Maesa lanceolata & 1 & 0.65 & 4 & 0.43 & 0.07 & 0.03 & 1.11 \\
\hline Aidia micrantha & 6 & 3.92 & 26 & 2.78 & 0.81 & 0.29 & 7.00 \\
\hline
\end{tabular}

